IZA DP No. 4184

Trade and Unemployment:

What Do the Data Say?

Gabriel Felbermayr

Julien Prat

Hans-Jörg Schmerer

May 2009 


\title{
Trade and Unemployment: What Do the Data Say?
}

\author{
Gabriel Felbermayr \\ University of Stuttgart-Hohenheim \\ Julien Prat \\ University of Vienna, \\ New York University and IZA \\ Hans-Jörg Schmerer \\ University of Tübingen and \\ University of Stuttgart-Hohenheim
}

Discussion Paper No. 4184

May 2009

IZA

P.O. Box 7240

53072 Bonn

Germany

Phone: +49-228-3894-0

Fax: +49-228-3894-180

E-mail: iza@iza.org

Any opinions expressed here are those of the author(s) and not those of IZA. Research published in this series may include views on policy, but the institute itself takes no institutional policy positions.

The Institute for the Study of Labor (IZA) in Bonn is a local and virtual international research center and a place of communication between science, politics and business. IZA is an independent nonprofit organization supported by Deutsche Post Foundation. The center is associated with the University of Bonn and offers a stimulating research environment through its international network, workshops and conferences, data service, project support, research visits and doctoral program. IZA engages in (i) original and internationally competitive research in all fields of labor economics, (ii) development of policy concepts, and (iii) dissemination of research results and concepts to the interested public.

IZA Discussion Papers often represent preliminary work and are circulated to encourage discussion. Citation of such a paper should account for its provisional character. A revised version may be available directly from the author. 


\section{ABSTRACT}

\section{Trade and Unemployment: What Do the Data Say?*}

This paper documents a robust empirical regularity: in the long-run, higher trade openness is causally associated to a lower structural rate of unemployment. We establish this fact using: (i) panel data from 20 OECD countries, (ii) cross-sectional data on a larger set of countries. The time structure of the panel data allows us to deal with endogeneity concerns, whereas cross-sectional data make it possible to instrument openness by its geographical component. In both setups, we carefully purge the data from business cycle effects, include a host of institutional and geographical variables, and control for within-country trade. Our main finding is robust to various definitions of unemployment rates and openness measures. The preferred specification suggests that a 10 percent increase in total trade openness reduces unemployment by about one percentage point. Moreover, we show that openness affects unemployment mainly through its effect on TFP and that labor market institutions do not appear to condition the effect of openness.

JEL Classification: F16, E24, J6

Keywords: international trade, real openness, unemployment, GMM models, IV estimation

Corresponding author:

Gabriel Felbermayr

University of Stuttgart-Hohenheim

Economics Department

70593 Stuttgart

Germany

E-mail: gabriel.felbermayr@uni-hohenheim.de

\footnotetext{
* We are very grateful to Luca De Benedictis, Peter Egger, Benjamin Jung, Wilhelm Kohler, Devashish Mitra, Christopher Pissarides, Richard Upward, as well as participants at the CESifo Munich-Tübingen workshop, and workshops at the Universities of Aarhus, Göttingen, Leicester and Nottingham.
} 


\section{Introduction}

Does exposure to international trade create or destroy jobs? In the short run, trade liberalization increases job turnover as workers are reallocated from shrinking to expanding sectors. ${ }^{1}$ Empirical evidence suggests that those adjustments temporarily raise frictional unemployment on the aggregate level, as documented by Trefler (2004) for the case of NAFTA. On the other hand, the long run effect of trade liberalization on the equilibrium rate of unemployment is less clear. ${ }^{2}$

A burgeoning literature introduces labor market imperfections into workhorse models of international trade. Most papers conclude that trade openness matters for the equilibrium rate of unemployment; however, the sign of the relationship differs across papers. Blanchard (2006) talks about an "overabundance of theories" of wage setting and unemployment. Interacted with different explanations for international trade (comparative advantage versus product differentiation models), the number of possible theoretical frameworks is large. Brecher (1974) and Davis (1998) incorporate minimum wages into Heckscher-Ohlin models and find that trade liberalization can exacerbate unemployment. Davidson and Matusz $(1988,1999)$ introduce frictional unemployment in models of comparative advantage and find that the sign of the relationship depends on a comparison of capital-labor endowments across countries. Egger and Kreickemeier (2009) introduce fair wages into a model with increasing returns to scale and find that trade liberalization increases unemployment. Felbermayr, Prat, and Schmerer (2008) introduce search frictions into a similar trade model and find that unemployment is likely to be decreasing in the degree of openness. Helpman and Itshoki (2008) also use the search-matching approach, but combine comparative advantage motives and increasing returns to scale. They find that globalization can increase unemployment. ${ }^{3}$

The state of the theoretical literature therefore suggests to turn towards an empirical assessment. As stated by Davidson and Matusz (2004), whether trade affects the level of equilibrium unemployment is "primarily an empirical issue". Yet, "there is very little empirical work on the aggregate employment effects of trade policies". This paper attempts to shed some light on this question. Rather than testing a specific theoretical model, it

\footnotetext{
${ }^{1}$ See Bernard, Redding and Schott (2007) for a recent paper.

${ }^{2}$ Paul Krugman (1993) famously argues that "... the level of employment is a macroeconomic issue, depending in the short run on aggregate demand and depending in the long run on the natural rate of unemployment, with microeconomic policies like tariffs having little net effect." However, theoretical considerations, as well as empirical evidence suggest that at least some microeconomic policies-such as product market regulation-do affect the structural rate of unemployment; see Blanchard and Giavazzi (2003) for the theoretical argument and Bassanini and Duval (2006) for a survey of the empirics.

${ }^{3}$ The theoretical literature is large and quickly growing; our short summary cannot be but a very incomprehensive list of papers.
} 
presents the results of a thorough quest for the causal relationship between the rate of unemployment and openness in cross-sections of countries. There are two important challenges on the way. First, published data on unemployment rates are notoriously unreliable, with measurement bias systematically related to determinants of unemployment. Moreover, good data on labor market regulation is available only for a few countries. Second, the incentive for politicians to erect trade barriers as a response to unemployment shocks, may introduce a negative spurious correlation between unemployment and openness. If the timing of trade liberalization and labor market reform coincide, domestic demand shocks will concurrently reduce unemployment and increase imports.

We tackle the data quality problem by focusing on two different samples. We start with a high-quality data set of 20 rich OECD countries, provided by Bassanini and Duval (2009). Great efforts have been made at the OECD to construct unemployment rates and indicators of various labor market institutions with meaningful time and cross-sectional variance. In a second step, we use a lower-quality cross-section of countries, for which we average yearly unemployment rates from various data sets such as provided by the World Bank, the International Labor Organization, the International Monetary Fund, or the CIA and draw on labor market variables provided by Botero et al. (2004). To avoid endogeneity problems, we do our best to purge the data from business cycle effects and we use a comprehensive set of variables to control for labor market institutions. To address simultaneity bias in the OECD panel, we use various GMM-based techniques and exploit the time dimension of the data to construct instruments. In the cross-section, we use the geographical component of trade openness as an instrument.

Across different econometric models, different specifications, and different data sources, we are able to flesh out an important and robust result: the structural rate of unemployment is a non-increasing function of openness to trade. In the largest share of our regressions, higher trade openness actually decreases unemployment. In some exercises, it is irrelevant but never turns out to be positively correlated with unemployment. We find the following additional results. (i) There is no evidence that the effect of openness on unemployment is biased upwards due to endogeneity. Quite to the contrary, we find that OLS yields a negative bias, which signals that attenuation bias due to non-systematic measurement error in the openness measure (which biases results to zero) dwarves the endogeneity bias. (ii) Controlling for endogeneity is nevertheless crucial when comparing the effects of import openness with that of export openness. OLS-type models overestimate (in absolute values) the effect of import openness, but underestimate that of export openness. This is an interesting result that is fully in line with intuition: policy makers may react to adverse labor market shocks by restricting imports and by promoting exports. Hence, the correlation between the shock and the openness is negative for imports and positive 
for exports, leading to a positive bias in the first instant and a negative one in the second. (iii) It is important to adjust the openness measures for differences in the relative prices of non-traded goods, as suggested by Alcalá and Ciccone (2004) in the context of cross-country growth regressions. In particular, the unadjusted openness measure tends to exaggerate the effect of openness on unemployment. ${ }^{4}$ (iv) We investigate potential channels through which openness may affect the rate of unemployment. The strongest one is through total factor productivity (TFP). Openness increases TFP, as is well known in the growth literature. In turn, TFP has a strong negative effect on the rate of unemployment. For other channels-the capital/labor ratio, the degree of labor market distortions, or the amount of product market competition-we do not obtain clear-cut results over samples and specifications. (v) We do not find that the effect of openness is strongly and robustly conditioned by the capital/labor ratio, or the extent of labor or product market regulation.

Related literature. Apart from the theoretical literature discussed above, our exercise is closely related to two important strands of empirical research. First, labor economists have long estimated cross-country unemployment regressions, usually based on panel data for a restricted sample of rich OECD countries. Following Blanchard and Wolfers' (2000) seminal paper, the literature is mainly concerned with the explanatory power of labor market institutions and macroeconomic shocks. Nickell et al. (2005) provide a recent example of this approach, whereas Bassanini and Duval (2009) present a comprehensive survey. The terms "international trade", "openness" or "globalization" do not appear in their comprehensive 130 pages study. Hence, it appears to us that the role of international trade in cross-country regressions has not yet been thoroughly addressed. ${ }^{5}$ To connect our results with previous research, we closely follow the received methodology since we use similar data, econometric techniques and specifications. To the best of our knowledge, this paper is the first to systematically assess the role of trade openness for unemployment within the context of standard cross-country unemployment regressions for OECD countries. ${ }^{6}$ Surprisingly enough, the influence of trade turns out to be much more robust than that of many labor market institutions.

We also incorporate insights from the large empirical literature about the effect of

\footnotetext{
${ }^{4}$ Note that this issue is of much less concern in our panel analysis, where we can effectively control for the time-invariant component of cross-country variation in relative prices.

${ }^{5}$ Scarpetta (1996) uses an index measuring the pervasiveness of trade restrictions to proxy the intensity of competition. One also should add that many papers interact terms-of-trade shocks with labor market variables. However, they do not use the level of openness as an independent covariate. Boulhol (2008) interacts trade openness with labor market institutions, but does not address the endogeneity problem.

${ }^{6}$ The report of the European Economic Advisory Group at CESifo (2008) also includes some crosscountry regressions of unemployment rates on openness, but does not attempt to sort out correlation from causality.
} 
trade openness on per capita income. Frankel and Romer (1999) have proposed an instrumentation strategy based on geography which is, as a matter of fact, applicable only in cross-sections. The consensus is that the positive effect of openness on per capita income is not robust to seemingly unrelated geographical controls, such as the distance to equator. ${ }^{7}$ Their paper has triggered a debate on the relative importance of trade, institutions, and the common underlying exogenous driver, geography. Prolonging this line of investigation, a recent paper by Dutt et al. (2009) test specific implications of the Davidson and Matusz (1999) model using cross-country regressions and a geography-based instrument. Although their sample, data sources and methodology are different, their results are qualitatively in line with ours. Interestingly, our own IV estimates, much inspired by the approach of Alcalá and Cicone (2004), suggest a negative relationship between openness and unemployment that is robust to inclusion of variables such as distance to equator or general institutional controls.

Structure of the paper. In section 2 we provide a brief first glance at the data. We identify our two key concerns about data quality and endogeneity bias. This motivates section 3, where we sketch the empirical strategy for our different data sets. Section 4 contains our core results on the trade-unemployment relation. We provide evidence for a high-quality OECD panel with relatively narrow country coverage, a larger cross-section of countries, and a short-panel with a greater number of countries. We contrast import and export openness, and compare the real measure proposed by Alcalá and Ciccone (2004) to the traditional one used, e.g., in Frankel and Romer (1999). Section 5 presents additional results on the channels through which openness affects labor markets and on interactions between labor market institutions, the capital-labor ratio, and trade. It also discusses a large number of robustness checks with the details relegated to a supplement paper. ${ }^{8}$ Finally, section 6 concludes.

\section{A descriptive look at the data}

As a first step, this section discusses the data that we use in our empirical exercise: unemployment rates and different measures of openness to international trade. It also provides a first heuristic look at the unemployment-openness relationship. A detailed discussion of the data is contained in the Appendix.

\footnotetext{
${ }^{7}$ See, for example, Rodriguez and Rodrik, 2000.

${ }^{8}$ The supplement paper, do files, and our data are available at http://sites.google.com/site/gfelberm.
} 


\subsection{Data sources and variables}

\subsubsection{Unemployment rates}

International institutions such as the OECD, the World Bank or the International Labor Organization (ILO) provide harmonized unemployment rates that are calculated following the same conventions. Across different international institutions, these rules can differ. For example, the rates published by the OECD or the World Bank rely on national administrative sources, while the ILO data is based on labour market surveys. The former strategy presupposes the cooperation of national statistical agencies; the latter is probably better suited to developing countries. Country coverage is always an issue: While the World Bank has 185 members, in the year 2000 it reports unemployment rates only for 93 of them. The ILO data exhibits an ever lower degree of country coverage (86 countries).

However, in all cases the accuracy of the published rates depends on the quality of the data delivered by the institutions' member states. Data quality is only a minor issue for the 20 rich OECD countries, but appears to be highly problematic for the rest of the world. ${ }^{9}$ The correlation between unemployment rates from these different data sets is strikingly low within the group of low-income, low-openness countries, which suggests that data quality systematically depends on country characteristics. Such non-random measurement error in our dependent variable (the rate of unemployment), however, will tend to bias the absolute value of the estimated effect of openness upwards.

Unfortunately, there is very little that one can do about data quality problems except running as many robustness checks as possible or working with the small panel of OECD countries for which data quality is satisfactory. ${ }^{10}$ Hence, in a first step, we focus on 20 high-quality OECD countries, for which systematic measurement bias in the rate of unemployment is unlikely (but where the analysis may suffer from non-random sample selection). This choice strongly limits the cross-sectional scope of our analysis and makes it necessary to use panel data and rely on time-variance for estimation. In addition, we perform purely cross-sectional regressions with larger country samples and also experiment with a short panel for this larger sample. To verify the robustness of our results, we use different data sources for the dependent variable (unemployment rate).

\footnotetext{
${ }^{9}$ In its statistical factbook, the CIA publishes yearly estimates of unemployment rates for a larger sample of countries (as of 2000, there is data for 160 countries). The CIA makes use of all publicly available information plus the insider information of its employees. How exactly the CIA experts obtain these estimates is not made explicit. In the non-OECD sample, average CIA estimates are substantially larger than the information provided by official sources; in the OECD sample there is no such gap.

${ }^{10}$ More details on countries included is provided in the Appendix.
} 


\subsubsection{Openness measures}

The summary measure of trade openness nearly always used in empirical work is nominal imports plus exports relative to nominal GDP, usually referred to as (trade) openness and denoted by $T$. For recent examples see Coe and Helpman (1995), Frankel and Romer's (1999), Ades and Glaeser (1999), Alesina, Spolaore and Wacziarg (2000), Dinopoulos and Thompson (2000) or Alcalá and Ciccone (2004). The openness measure has the advantage that it reflects the actual exposure of an economy to international trade and is easily measurable. Trade policy itself is often hard to observe, in particular because of the declining importance of tariffs or quotas and the increasing use of informal trade barriers. Also, membership in regional trade agreements or the WTO does not necessarily provide information about the actual openness of an economy, see Rose (2005).

There are some obvious alternatives to the standard definition of $T$ that may be relevant in the openness-unemployment debate. First, since imports and exports need not coincide, and rising imports may have a different effect on unemployment than increasing exports, one could redefine $T$ as nominal imports or exports over nominal GDP. Second, Alcalá and Ciccone (2004) argue that the Balassa-Samuelson effect distorts nominal price openness measures since countries with low labor productivity and hence a high price of traded relative to non-traded goods have artificially high degrees of openness. They propose to use real openness defined as imports plus exports in exchange rate US\$ relative to GDP in purchasing-power-parity US\$ (PPP GDP). This eliminates cross-country differences in the relative price of non-traded services from the summary measure of trade. They show how the real openness measure can be computed using data provided in the Penn World Tables (PWT). The measure of real openness may be particularly relevant to the extent that the effect of trade openness on aggregate unemployment works through total factor productivity. We use real total trade openness constructed according to Alcalá and Ciccone (2004) as our benchmark measure. Even if accounting for the Balassa-Samuelson effect is not a big issue for countries in our OECD sample, the problem becomes more severe in our large cross sectional regressions. Comparing real and current price openness measures reveals that the effect is smaller for real openness but coefficients are more stable across different models and setups. ${ }^{11}$

As with unemployment rates, the openness measures may be noisy proxies for the actual degree of exposure to international trade. However, it is less obvious that measurement error should be systematically related to any determinant of the unemployment rate.

\footnotetext{
${ }^{11}$ In our robustness checks, we also work with constant price openness measures which fix all prices at some base year. Moreover, data provided by the World Bank allows to focus on merchandize trade only. This allows to see whether trade in services has a different effect on unemployment compared to trade in goods.
} 
Random measurement error would bias estimated towards zero, making it harder for us to find significant effects. The real challenge therefore lies in the potential endogeneity of openness to adverse labor market shocks.

\subsubsection{Labor market institutions}

The OECD has collected data on a wide array of institutional variables that can be expected to affect the equilibrium rate of unemployment. Bassanini and Duval (2009) discuss the data in detail. These measures include the degree of union density or of union coverage, the extent of employment protection legislation or of active labor market policies, effective average tax rates on wages, the average replacement rate of unemployment insurance, the degree of corporatism and many more. The data also includes a measure of product market regulation which reflects entry barriers. These variables are available for 20 rich OECD countries, and for most of them we have time series ranging from $1980-2003$.

The data for the wider cross-section of countries is more problematic. By far the most careful data collection has been undertaken by Botero et al. (2004). They provide a data set containing data on various aspects of labor market regulations for 85 countries. Observations range from 1990 - 2000 and were averaged over the whole period. In our study we focus on measures related to the generosity of unemployment benefits, the extent of employment protection (EPL) and the importance of minimum wages. Additionally to those labor market regulations Botero et al. also collected data on the size of the informal economy. Reported unemployment rates and the degree of openness may both be systematically related to the size of the shadow economy so that omitting this variable could easily bias the effect of trade. This is a particularly important issue in the large cross-section, where we cannot control for unobserved heterogeneity and where we have a large number of developing countries.

The Botero et al. data does not contain a time dimension. Therefore, when running panel regressions for the large country sample, we need to rely on data from the Fraser Freedom of the world data base, where we have variables on unemployment benefits, labor market institutions and product market regulations. The former variable is an index that collects information on many dimensions of labor market institutions; the latter quantifies the extent of price controls. ${ }^{12}$ Observations for 116 countries are available in five year intervals beginning in 1975 and ranging until 2005.

\footnotetext{
${ }^{12}$ In the original Fraser data higher values indicate more freedom and thus less regulation. To avoid confusion when comparing with the OECD or the Botero et al. data we rescale the Fraser variables by the factor -1 .
} 


\subsection{A first glance at the openness-unemployment nexus}

\subsubsection{Time variance in the OECD sample.}

The solid line in Figure 1 plots the unweighted average unemployment rate of 20 rich OECD countries (see the Appendix for a list of countries). Starting from a low level at about 2 percentage points in 1970 , the unemployment rate increased over time to reach a peak of 10 percent in the mid-nineties, but fell back to about 6 percent in 2003. Not surprisingly, the unemployment rate exhibits substantial cyclical variation. Measured on the right vertical axis of Figure 1, the unweighted average share of trade in total GDP (measured as real openness) also displays a clear upward trend: it increased from about 25 percent in 1970 to about 40 percent in the early years of the new millennium. The trade share also displays cyclical variation, albeit at a smaller degree. Hence, in the OECD sample, average unemployment rates and the average real openness appear positively correlated over time.

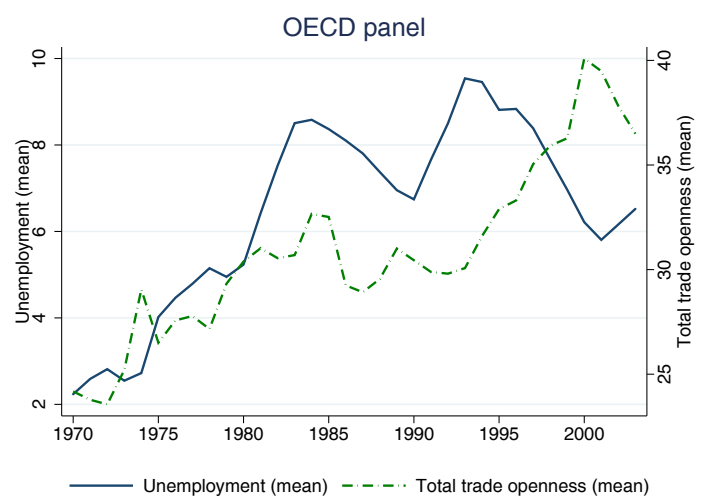

Figure 1: Unemployment and openness

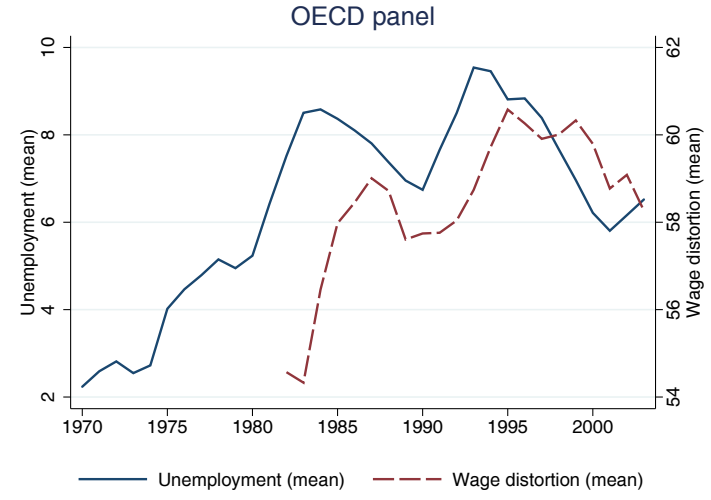

Figure 2: Unemployment and wage distortion

So far, the empirical labor market literature has usually not accounted for any measure of trade openness. Nickell et al. (2005) show that the evolution of labor market institutions has substantial explanatory power for unemployment rates. In particular, tax rates and replacement rates perform well; other institutional variables do not yield robust results. This is not entirely surprising since the theoretical predictions relating to employment protection legislation or union coverage are usually ambiguous. Costain and Reiter (2008) use a theoretical model to argue that tax and replacement rates should have similar qualitative and quantitative effects in a search and matching model of unemployment. They propose to add them. The obtained index consists of the sum of the average wage tax burden and social benefits foregone when a worker switches from unemployment into a job. It therefore measures the total fiscal burden imposed on the worker (see also Saez (2002); Immervoll et 
al. (2007)) and is sometimes referred to as the participation tax. Figure 2 shows that the average wedge and average unemployment are also positively correlated over time. Hence, the prima facie evidence suggests that it is important to control for both variables in any meaningful cross-country unemployment regression that draws on time variance. ${ }^{13}$

Figures 1 and 2 present sample averages over time and fully disregard heterogeneity across countries. In a next step we correlate first-differences of the real openness measure against first-differences in the unemployment rate. Differencing should eliminate countryspecific effects unrelated to openness that may drive the correlation in Figure 1. Figure 3 shows the scatter plot and fits a univariate linear regression. The slope of the line is estimated at -0.04 with a t-value of 5.69. This preliminary evidence points towards a negative effect of trade openness on the rate of unemployment. A one-standard deviation increase (about 10 percentage points) of openness is associated to a decrease in the rate of unemployment of about 0.4 percentage points. Interestingly, our more elaborate multivariate instrumental variable analysis below suggests results of very similar magnitude.

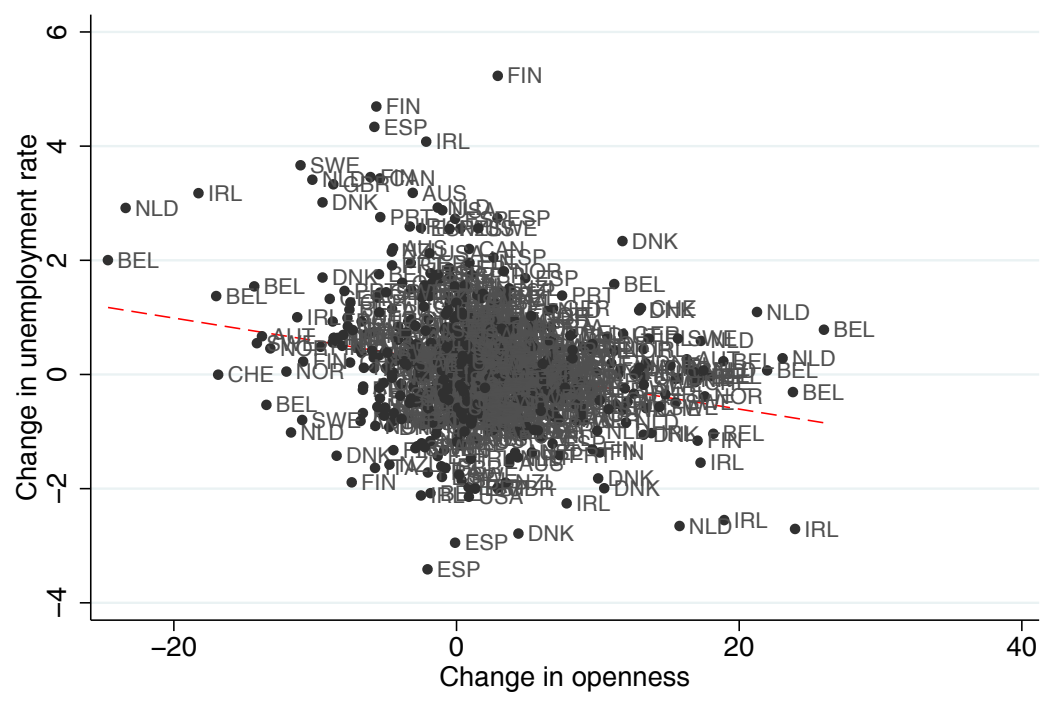

Figure 3: Unemployment and trade openness: first differences (OECD sample)

\subsubsection{Cross-sectional variance in the large sample}

Figure 4 sets the average level of unemployment (WDI estimates) against the average level of openness (real current price) for the largest cross-section of countries, for which we have

\footnotetext{
${ }^{13}$ In the picture, the unemployment rate leads the measure of wage distortion over time. Costain and Reiter (2008) discuss the endogeneity issues suggested by this fact but conclude that they are unlikely to pose any serious problems.
} 
data. Averages are based on the period from 1990-2006, but there may be substantial spans of missing values within that period.

The linear regression line fitted to the scatter plot has a slope of about -0.044 with a t-value of 2.20. ${ }^{14}$ Hence, also in the large cross-section of countries, the unconditional regression of openness on the rate of unemployment yields a negative correlation. Because the variance of the openness measure is much larger in the large cross-section than in the narrow OECD sample, the point estimate implies that a one-standard deviation increase of openness is associated to a decrease in the rate of unemployment by about 1 percentage point.

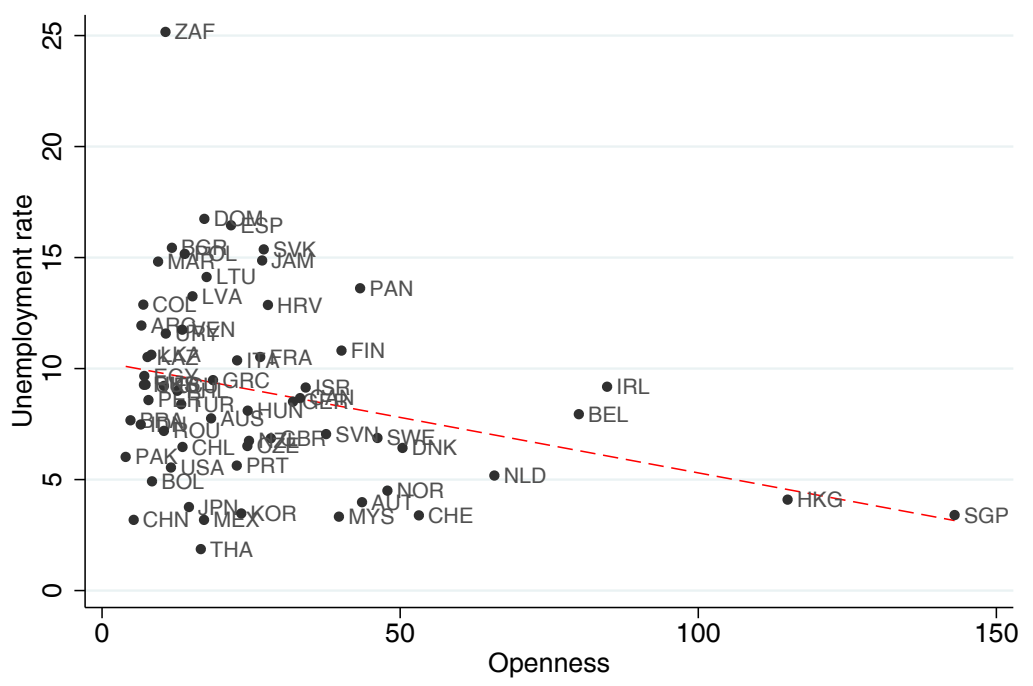

Figure 4: Unemployment and trade openness: averaged levels (large cross-section)

\subsection{Implications and challenges}

The above figures are suggestive. However, they cannot establish a causal relationship. There are several reasons why the correlations in figures 3 and 4 may be spurious. First, while we have used yearly data, there may be business cycle effects: any positive shock on domestic spending is likely to increase domestic as well as import demand. This lowers unemployment and increases openness. Second, in periods of reform, countries may simultaneously liberalize their product and labor markets, leading to a simultaneous increase in openness and employment. Third, politicians may react to shocks in the unemployment rate by imposing protectionist measures. More precisely, they may resort to policy measures that discourage imports and encourage exports; since the overt use of tariffs, quotas,

\footnotetext{
${ }^{14}$ The finding of a negative slope is robust to the exclusion of HKG (Hong Kong) and SGP (Singapore); statistical fit is improved by taking logs of both variables.
} 
or subsidies is strongly restricted by international agreements, governments may use nontariff measures which are difficult to control for directly. In the case that import-restricting policies dominate, the rise in unemployment would be associated with a reduction in openness.

We deal with the first problem, the business-cycle effect, in the following way. In the OECD sample, we take 5-year averages to smooth out business cycle variation. Moreover, in all regressions we include a measure of the output gap, based on HP filtering methods, and provided by Bassanini and Duval (2009). In the larger cross-section, we take averages over the entire available period (1990-2006). We also include the output gap.

The second issue relates to an omitted variables bias. In the OECD sample, we can draw on high-quality data provided by Bassanini and Duval (2009). For the wider sample, we use the variables provided by Botero et al. (2004). See the Appendix for a detailed description of all our data.

The third and most interesting problem is a classical simultaneity problem. We can only address it by instrumenting the openness measures. In the case of the OECD panel, we can exploit the time-variance of the data and use lagged differences and levels as instruments. In the case of the wider cross-section, we draw on the instrument proposed by Frankel and Romer (1999) and used, i.a., by Alcalá and Ciccone (2004). We have opposite expectations concerning the sign of the endogeneity bias for import openness and export openness. This provides us with a natural external check of our instrumentation strategy.

\section{Empirical strategy}

We have to adapt our econometric strategy to the nature of the available data. For the OECD sample, where we can draw on meaningful time-variance, we build on the rich tradition of empirical labor market studies surveyed in Bassanini and Duval (2009) and use panel methods. For the wider sample, we use the cross-sectional approach which has been widely employed in the growth-openness literature. While time-variance in the larger cross-section is somewhat problematic, we still check our results by running panel regressions as well.

\subsection{OECD sample: GMM panel regressions}

We extend Nickell et al. (2005) and estimate variants of a dynamic model

$$
u_{i, t}=\sum_{s=1}^{S} \rho_{s} u_{i, t-s}+\beta \cdot T_{i, t}+\lambda \cdot \mathbf{L M I}_{i, t}+\pi \cdot \mathbf{P M R}_{i, t}+\gamma \cdot G A P_{i, t}+\nu_{i}+\nu_{t}+\varepsilon_{i, t},
$$


where $S$ is the number of lags of the endogenous variables. All variables are five-year averages. The vectors $\mathbf{L M I}_{i, t}$ and $\mathbf{P} \mathbf{M R}_{i, t}$ collect variables measuring labor market institutions and product market regulation, respectively. $G A P_{i, t}$ is the output gap, ${ }^{15} \nu_{i}$ is a vector of country-specific effects, $\nu_{t}$ denotes time effects, and $\varepsilon_{i, t}$ is an error term. We are primarily interested in the estimate of $\beta$ and expect that the effects of LMI and PMR conform with the evidence surveyed in Bassanini and Duval (2009). This evidence is mixed: Baker et al. (2004) show that those panel data estimations lack robustness and that clear results on the role of most labor market institutions hardly exist. There is, however, an emerging consensus that replacement rates and the tax wedge have a robust and theoretically sensible effect; see Costain and Reiter (2008).

The (preferred) equation estimated by Nickell et al. (2005) is similar to (1), but does not include openness. They use generalized least squares techniques on this equation and are not particularly worried by the potential endogeneity of labor or product market institutions. Many of the specifications surveyed in Bassanini and Duval (2009) constrain $\rho_{s}=0$ and estimate static fixed effects models. Some papers use the log of $u_{i, t}$ as the dependent variable (Nickell, 1997; Costain and Reiter, 2008), but there does not seem any consensus as to which specification is preferred. In our baseline specifications, we use $u_{i, t}$ in levels, but provide robustness checks for the logarithmic case.

We address the potential endogeneity of openness and of the lagged dependent variable by instrumenting with the respective lagged values. ${ }^{16}$ In the first-differenced general method of moments (diff-GMM) approach by Arellano and Bond (1991), all variables are differenced and endogenous variables are instrumented by their lags (in differences). The more general approach proposed by Blundell and Bond (1998) adds level equations to the differenced ones. This leads to a system of two different sets of moment conditions (differences and levels). Blundell and Bond use Monte Carlo simulations to show that the sys-GMM approach is more efficient since a larger number of moment conditions is available. All techniques discussed above allow to control for potential endogeneity, even when there is no obvious instrument waiting on the wing. Nevertheless those GMM approaches must be treated cautiously since small degrees of model specification error may induce large effects on results and lagged variables might be weak instruments. There are however, a number of tests that can be used to check whether the conditions of the approach are fulfilled. For both GMM methods, two requirements must hold: $i$ ) the instruments

\footnotetext{
${ }^{15}$ For the OECD output gap is measured as derivation of actual output from potential output (Basanini and Duval (2009). For the large cross section we use a proxy constructed as difference between actual GDP and trend GDP. The latter is obtained by HP-filtering the data, where the smoothing parameter is set to 400 .

${ }^{16}$ Additionally, we treat the wage distortion index (sum of average replacement rate and tax wedge) as endogenous.
} 
must be uncorrelated with the error term and $i i$ ) the instruments must be correlated with the instrumented variable. Both types of GMM are valid if we find evidence in favor of first order, but against second order auto correlation in the residuals. ${ }^{17}$

\subsection{Large cross-section of countries: 2SLS regressions}

To extend the analysis beyond the 20 rich OECD countries, we focus on a pure crosssection of countries. This approach is strongly related to cross-country income regressions (Frankel and Romer, 1999; Alcalá and Ciccone, 2004), with the most important difference being the different choice of dependent variable.

We estimate the following second stage regression

$$
u_{i}=\alpha+\beta \cdot T_{i}+\lambda \cdot \mathbf{L} \mathbf{M I}_{i}+\pi \cdot \mathbf{P M R}_{i}+\delta \cdot \mathbf{G E O}_{i}+\iota \cdot \mathbf{I N S T}_{i}+\gamma \cdot G A P_{i}+\varepsilon_{i},
$$

which includes the same type of controls than (1). Since we have no reliable time-variance available to control for unobserved country-specific fixed effects, we have to add geographical variables to control for the size of the home-market and hence the importance of within-country trade as compared to international trade. Frankel and Romer (1999) and much of the following literature use the log of population and the log of land area of country $i .{ }^{18}$ Regressions also contain a continuous measure of landlockedness as an additional strictly exogenous control. We proxy for the overall quality of institutions by including distance to the equator and continent dummies.

We follow Frankel and Romer (1999) and instrument $T_{i}$ by its (exogenous) geographical component; however, our strategy is somewhat more general. It consists in using bilateral trade data (for the year of 2000) and regress total trade (exports plus imports) between country $i$ and $j$, normalized by country $i^{\prime} s$ GDP, on geographical determinants of trade in an equation of the type

$$
T_{i j}=\exp \left[\varphi \mathbf{X}_{i j}\right] \cdot v_{i j}
$$

The vector $\mathbf{X}$ contains the $\log$ of bilateral distance between $i$ and $j$, the $\log$ of population of $i$ and $j$ as of year 1960, the $\log$ of land area of $i$ and $j$, and a continuous measure of landlockedness. It also contains interactions of all those terms with an adjacency dummy. All of the elements in $\mathbf{X}$ are exogenous while $v_{i j}$ is an error term.

The standard procedure is to take logs of (3) and estimates the vector $\varphi$ using OLS. Since $T_{i j}=0$ for many country pairs, we follow Santos and Tenreyro (2006) and estimate

\footnotetext{
${ }^{17}$ We have also experimented with the Anderson and Hsiao approach where lagged variables are used as instruments when estimating two stage least square IV regressions. Results are available on request.

${ }^{18}$ While standard in the related literature and crucial for the interpretation of the results, Dutt et al. (2009) do not include these controls.
} 
(3) using Poisson pseudo maximum-likelihood. Predicting $\hat{T}_{i j}$ and summing over $j$, we have a measure of the trade share $\hat{T}_{i}$ that is by construction orthogonal to unemployment and hence a valid instrument. ${ }^{19}$ The Poisson approach leads to a stronger instrument since we do not have to omit the information contained in the zero trade observations and need not resort to out-of-sample predictions to construct the instrument. ${ }^{20}$

\subsection{Large sample: Panel regressions}

In the setup described in section 3.2, we have averaged yearly available unemployment data for a large set of countries into a cross-section. This seems appropriate to deal with business cycle effects and should also help to reduce (non-systematic) measurement error in both the dependent and the independent variables. However, it is possible to generate averages over shorter periods of time (five years), stack data from different periods, and use panel methods. The drawback of this approach is that unemployment data are available only for a very small sample for a long time horizon so that we end up with a strongly unbalanced panel. However, applying panel methods still allows to check the overall robustness of our results in 3.2 to country-specific unobservable effects.

We use the same econometric specification than the one used on OECD data, see equation (1). Since we need time-variant information about labor and product market regulation, we cannot use the Botero et al. (2004) data, but have to work with variables provided by the Fraser institute.

\section{The effect of openness on unemployment}

In the following section, we present benchmark results for our different samples, empirical strategies and IV strategies. We also study the different impact of export versus import openness. The overall picture is fairly robust and surprisingly clear-cut: regardless of the precise econometric model used, independent from the exact source of data or the definition of the employed openness measure or the nature of controls we find that higher openness does not increase unemployment. In most regressions, openness strictly lowers the equilibrium rate of unemployment. We are able to establish that our findings reflect the causal effect of openness on trade rather than spurious correlations.

\footnotetext{
${ }^{19}$ Note that validity of the instrument does not require that the coefficients associated to $\mathbf{X}$ are consistently estimated parameters of a gravity equation. Rather, equation (3) is a constructed exogenous measure of multilateral resistance.

${ }^{20}$ Noguer and Siscart (2005) show that out-of-sample predictions has important adverse implications for the strength of the instrument.
} 


\subsection{Benchmark results}

\subsubsection{OECD sample: panel regressions}

Table 1 presents panel regressions for 20 rich OECD countries. The dependent variable is the rate of unemployment in the total working age population (age 15-64). All variables are five-year averages ranging from $1980-2003 .{ }^{21}$ Robust standard errors are reported. A list of countries used in these regressions is provided in the Appendix.

Columns (1) and (2) show standard regressions as carried out by Bassanini and Duval (2009). The first treats country-effects as fixed, the second treats them as random, everything else is equal. We let a Hausman test decide which of the two specifications is preferred. In all cases presented in Table 1 the test recommends the random effects (RE) specification over the fixed effects (FE) model.

The regressions reveal a well-known pattern: only a few labor market controls are statistically significant, and often the sign pattern seems to be counter-intuitive. The toughness of firing restrictions as reflected in employment protection legislation (EPL) is negatively associated to the rate of unemployment. Hence, firing restrictions seem to discourage job destruction more than job creation; however, the effect is not statistically distinguishable from zero. Similarly, we do not find any robust role for the degree of union density. The degree of wage distortion (the sum of the replacement rate and the average tax rate on wages) is positively related to the equilibrium unemployment rate. Statistically significant at the $1 \%$ level, an increase in the wedge by 10 percentage points increases the rate of unemployment by about 1 percentage point. Countries with a highly corporatist bargaining culture have an unemployment rate that is by about 2.3 percentage points lower than countries without this tradition. These findings are in line with the literature ${ }^{22}$ and the emerging consensus that the degree of wage distortion is the most important institutional variable in panel regressions ${ }^{23}$.

Although we average our data over five-year intervals to mitigate business cycle concerns, the output gap is strongly significant and has the expected negative sign. This shows that taking averages alone is not sufficient to purge out the business cycle. Also note that country-specific effects are important for the overall explanatory power of the model. A model that explains unemployment only by country-effects yields an $R^{2}$ statistic of about $63 \%$; adding year dummies improves the share of left-hand-side variance explained to $75 \%$.

\footnotetext{
${ }^{21}$ We have also run regressions on yearly data. Results are similar and statistical significance is usually higher. However we prefere to work with averages to better account for variations in the business cycle.

${ }^{22}$ As can be seen from the survey by Bassanini and Duval (2009) or the critical discussion in Baker et al. (2002).

${ }^{23}$ See Costain and Reiter (2008).
} 
In the random effects model shown in column (2), the exact variance decomposition shows that the within component is much larger than the between component.

Columns (3) and (4) include the real openness measure proposed by Alcalá and Ciccone (2004) into the fixed- and the random effects models, respectively. Again, the Hausman test recommends the more efficient $\mathrm{RE}$ model. The results imply that an increase in openness by 10 percentage points lowers the equilibrium rate of unemployment by about 0.73 percentage points. Inclusion of the openness measure increases the explanatory power (within $R^{2}$ ) of the regression by about 4 percentage points. Focusing on the RE specification and comparing the models with and without the openness measures, we find that the coefficients on the labor market variables change only very slightly so that omitted variable bias from not incorporating openness seems unimportant. This suggests that labor market regulation does not systematically correlate with the degree of openness. Also the output gap does not seem to covary with openness.

The remaining models presented in Table 1 are dynamic models. Column (5) uses the feasible generalized least square methodology proposed by Nickel et al. (2005) to estimate an autoregressive model. ${ }^{24}$ The lagged rate of unemployment has an estimated coefficient of about 0.37 , signalling that-over our five-year periods-unemployment rates are only mildly persistent, controlling for the output gap and labor market institutions. Again, the effect of openness is precisely estimated and negative. The short-run effect together with the autoregressive coefficient implies that a ten percentage point increase in openness lowers the equilibrium rate of unemployment by roughly one percentage point in the short-run, and by about 1.5 percentage points in the long-run. ${ }^{25}$

So far we have not dealt with the potential endogeneity of openness. Models (6) and (7) use lagged realizations or lagged differences of openness as instruments. In the first case, GMM estimation is applied to a differenced version of equation (1). In the second case, moment conditions from an additional level equation are used to increase efficiency. In both cases, we find that openness reduces unemployment. In the diff-GMM model (6), the short-run effect and the long-run effects are quantitatively comparable to the FGLS model. In the sys-GMM model (7), the short-run effect is smaller: a 10 percentage points increase in openness decreases unemployment by about 0.26 percentage points. The long run effect, however, is again comparable: a 10 percent openness increase leads to lower unemployment by 1.16 points. GMM methods are vulnerable to misspecification problems and applicable only under certain conditions. For both models, the OID tests for overidentification yield high p-values so that validity of the instruments cannot be rejected. ${ }^{26}$ Furthermore, the

\footnotetext{
${ }^{24}$ Their approach includes country effects into the regressions.

${ }^{25}$ Long-run coefficients are found at the fixed-point of the difference equation.

${ }^{26}$ Note that the tests remain stochastic $(p$-values $<1$ ) and consequently meaningful.
} 


\section{Table 1: Benchmark regressions: OECD panel}

\begin{tabular}{|c|c|c|c|c|c|c|c|}
\hline & (1) & $(2)$ & $(3)$ & $(4)$ & $(5)$ & $(6)$ & $(7)$ \\
\hline & $\mathrm{FE}$ & $\mathrm{RE}$ & $\mathrm{FE}$ & $\mathrm{RE}$ & FGLS & Diff-GMM & Sys-GMM \\
\hline Total trade openness & & & $\begin{array}{c}-0.113^{* * *} \\
(0.037)\end{array}$ & $\begin{array}{c}-0.072^{* * *} \\
(0.018)\end{array}$ & $\begin{array}{c}-0.096^{* * *} \\
(0.023)\end{array}$ & $\begin{array}{c}-0.106^{* *} \\
(0.046)\end{array}$ & $\begin{array}{c}-0.026^{* *} \\
(0.011)\end{array}$ \\
\hline Lag dep. var. & & & & & $\begin{array}{l}0.367^{* * *} \\
(0.050)\end{array}$ & $\begin{array}{l}0.400^{* * *} \\
(0.153)\end{array}$ & $\begin{array}{l}0.775^{* * *} \\
(0.054)\end{array}$ \\
\hline Wage distortion (index) & $\begin{array}{l}0.134^{* * *} \\
(0.040)\end{array}$ & $\begin{array}{l}0.111^{* * *} \\
(0.026)\end{array}$ & $\begin{array}{c}0.094^{* *} \\
(0.042)\end{array}$ & $\begin{array}{l}0.110^{\text {*** }} \\
(0.025)\end{array}$ & $\begin{array}{l}0.095^{\text {*** }} \\
(0.020)\end{array}$ & $\begin{array}{c}0.054 \\
(0.042)\end{array}$ & $\begin{array}{c}0.061^{*} \\
(0.035)\end{array}$ \\
\hline EPL (index) & $\begin{array}{c}-0.609 \\
(1.187)\end{array}$ & $\begin{array}{c}-0.642 \\
(0.541)\end{array}$ & $\begin{array}{c}-0.488 \\
(1.185)\end{array}$ & $\begin{array}{c}-0.533 \\
(0.540)\end{array}$ & $\begin{array}{c}-0.315 \\
(0.357)\end{array}$ & $\begin{array}{c}-0.516 \\
(0.820)\end{array}$ & $\begin{array}{c}-0.269 \\
(0.429)\end{array}$ \\
\hline Union density (index) & $\begin{array}{c}0.043 \\
(0.033)\end{array}$ & $\begin{array}{c}-0.007 \\
(0.028)\end{array}$ & $\begin{array}{c}0.034 \\
(0.034)\end{array}$ & $\begin{array}{c}0.005 \\
(0.027)\end{array}$ & $\begin{array}{l}0.037^{* *} \\
(0.016)\end{array}$ & $\begin{array}{c}-0.001 \\
(0.035)\end{array}$ & $\begin{array}{c}-0.035^{* *} \\
(0.016)\end{array}$ \\
\hline High corporatism (dummy) & $\begin{array}{c}-2.620^{* * *} \\
(0.828)\end{array}$ & $\begin{array}{c}-2.324^{* * *} \\
(0.730)\end{array}$ & $\begin{array}{c}-1.299 \\
(1.160)\end{array}$ & $\begin{array}{c}-1.592^{* *} \\
(0.702)\end{array}$ & $\begin{array}{c}-1.605^{* * *} \\
(0.487)\end{array}$ & $\begin{array}{c}-1.081 \\
(1.058)\end{array}$ & $\begin{array}{c}-1.030 \\
(0.966)\end{array}$ \\
\hline Output gap (\%) & $\begin{array}{c}-0.596^{* * *} \\
(0.086)\end{array}$ & $\begin{array}{c}-0.661^{* * *} \\
(0.114)\end{array}$ & $\begin{array}{c}-0.611^{* * *} \\
(0.092)\end{array}$ & $\begin{array}{c}-0.638^{* * *} \\
(0.112)\end{array}$ & $\begin{array}{c}-0.626^{* * *} \\
(0.054)\end{array}$ & $\begin{array}{c}-0.685^{* * *} \\
(0.080)\end{array}$ & $\begin{array}{c}-0.709^{* * *} \\
(0.086)\end{array}$ \\
\hline $\mathrm{R}^{2}$ (within) & 0.574 & 0.559 & 0.610 & 0.600 & & & \\
\hline $\mathrm{R}^{2}$ (overall) & 0.211 & 0.350 & 0.209 & 0.321 & & & \\
\hline $\mathrm{R}^{2}$ (between) & 0.121 & 0.274 & 0.094 & 0.220 & & & \\
\hline Hausman & \multicolumn{2}{|c|}{0.633} & \multicolumn{2}{|c|}{0.617} & & & \\
\hline OID test & & & & & & 0.249 & 0.967 \\
\hline $\operatorname{AR}(1)$ & & & & & & 0.007 & 0.016 \\
\hline $\operatorname{AR}(2)$ & & & & & & 0.524 & 0.553 \\
\hline
\end{tabular}

Robust standard errors in parentheses, ${ }^{*}$ significant at $10 \%,{ }^{* *}$ significant at $5 \%,{ }^{* * *}$ significant at $1 \%$. Number of observation $\mathrm{N}=100$ (20 countries observed for 4 5-year periods and 14 -year period; averages taken; 1980-2003). Hausman test p-values reported (Fixed effects estimator always consistent; random effects estimator efficient under Ho). All models control for unobserved country and period effects. FGLS allows for heteroscedastic errors and country specific first order serial correlation. First lag of dependent variable used for Feasible Least Square and Generalized Methods of Moments regressions. Diff- and Sys-GMM estimators are valid if i) OID test does not reject the $\mathrm{H} 0$ (H0: overidentifying restrictions are valid) and ii) if test on $\mathrm{AR}(1)$ is positive and negative on $\operatorname{AR}(2)$ (H0: no autocorrelation). Openness, output gap and wage distortion treated as endogenous in the GMM regressions. Maximum number of lags used as instruments equals one (22 instruments for diff-GMM and 37 instruments for sys-GMM). Constant estimated but not reported. 
$\operatorname{AR}(1)$ and $\operatorname{AR}(2)$ statistics suggest that the model is not misspecified.

Comparing (long-run) estimates across different columns of Table 1, we find that the point estimates of the openness coefficient are typically larger under the IV strategy. This is consistent with several explanations. First, the non-IV estimates may be biased down (in absolute value) due to endogeneity bias. This would happen if governments respond to adverse unemployment shocks by promoting exports such that total openness (reflecting imports as well) goes up. A second possibility, which we pursue in detail in section 4.2, is that the endogeneity biases of import openness and export openness are of opposite signs and that they offset each other in the measure of total openness. Third, the fact that non-IV estimates are biased towards zero may arise when our openness indicator is a noisy proxy of the true relevant degree of openness. Since instrumentation also remedies measurement error, this may explain the observed sign of the bias.

We have also run versions of the regressions shown in Table 1 under two modifications. Results are presented in the supplement paper (table 33). First, rather than using the total wage distortion (sum of replacement rate and tax rate), it uses both variables separately. Second, it adds a variable that has received much interest in the last years as a determinant of unemployment, namely the degree of product market regulation (PMR). ${ }^{2728}$ Qualitatively and quantitatively, the results are robust. However, the longer list of covariates makes it ever more difficult to ascertain the right specification of the GMM-sys estimations (the OID test statistic becomes non-stochastic), so that we have opted for the more parsimonious model in the body of the paper.

\footnotetext{
${ }^{27}$ See Felbermayr and Prat (2009) for theory and evidence on the role of PMR.

${ }^{28}$ We have also run regressions with the logarithm of population as an additional control. This variable will be crucial in the cross-sectional exercise. It is, however, qualitatively and quantitatively unimportant in the OECD panel exercise, most likely because the time variance of that variable is very low in that sample. In order to improve the performance of GMM models, we have to keep the models parsimonious enough, and therefore drop population.
} 


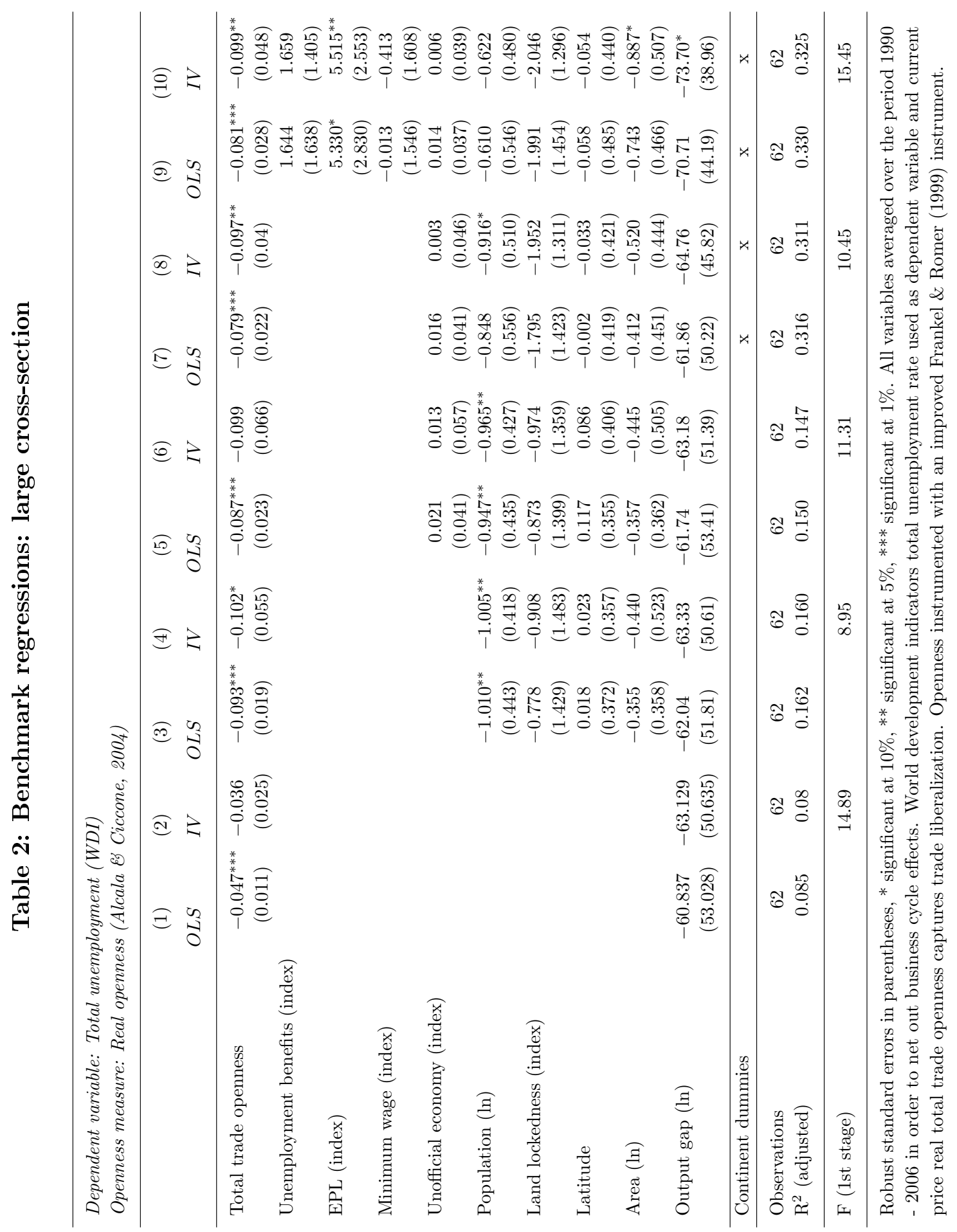


Moreover, the PMR indicator provided by the OECD partly reflects the degree of openness, so that its inclusion is potentially redundant. In section 5.1, we will test whether higher openness lowers unemployment precisely because it lowers the overall strictness of PMR.

\subsubsection{Large sample: cross sections}

Next, in Table 2, we study the effect of real openness in a cross-section of 62 countries. Unemployment rates are taken from the World Development Indicators data base provided by the World Bank. We average all variables over the window 1990-2006, so that business cycle effects are unlikely to contaminate the results. However, we still control for the output gap. We deal with endogeneity as described in section 3.2 by using an improved Frankel and Romer (1999) - type instrumentation strategy.

Column (1) is the most parsimonious model. It uses no additional controls (except the output gap whose inclusion is inconsequential). The OLS regression produces a coefficient of 0.047 , estimated with high precision, and implying that a 10 percentage points increase in openness lowers unemployment by about half a percentage point. When openness is instrumented, the point estimate is close to zero and statistical significance is lost. Hence, it appears that, in this very parsimonious model, OLS strongly overestimates the absolute size of the openness effect.

Column (3) and (4) are virtually identical to Table IV in Alcalá and Ciccone (2004) or to Table 3 in Frankel and Romer (1999), with the key differences being the different dependent variable and a slightly more general construction of the instrument. These papers stress the importance of including variables that control for the size of the domestic market (logarithm of population, the logarithm of land area, and a continuous measure of landlockedness). This is crucial since a country's degree of openness is negatively correlated to its own economic size. As suggested by theoretical arguments based on economic geography models, omitting the domestic market size control biases the openness coefficient away from zero if domestic market size is positively correlated to the unemployment rate, and biases it towards zero if it is negatively correlated. ${ }^{29}$ The regressions also include a rough proxy for institutional quality-the logarithm of distance to the equator (latitude). The IV estimate is now significant at the 1 percent level. It follows that the failure to produce a significant IV coefficient in column (2) is not due to endogeneity bias, but rather to omitted variable bias.

Models (5) and (6) add a variable provided by Botero et al. (2004), namely the size of the unofficial economy as a share of officially reported GDP. It is plausible to assume

\footnotetext{
${ }^{29}$ Assuming for simplicity that all covariates other than openness and domestic market size are uncorrelated, the bias is $\beta_{\text {size }} \times \operatorname{cov}($ open, size) $/ \operatorname{var}($ open).
} 
that more open economies have smaller unofficial economies, since exporting or importing requires formal clearing at the borders. It may also be the case that officially reported unemployment rates are inversely proportional to the size of the shadow economy. Indeed, in our data the discrepancy between estimates by the CIA and official data correlates with the size of the unofficial economy. Hence, it seems meaningful to control for the extent of the shadow economy. Compared to the results presented in columns (3) and (4), we find that this additional variable leaves the OLS estimates broadly unchanged but undoes the statistical significance of openness in the instrumental variable regressions. The size and sign of the estimates hardly moves. This is, however, not a robust result. For example, taking out latitude restores significance. More importantly, even with latitude included, we obtain fairly precise and roughly comparable estimates for both the OLS and the IV regressions when the model is augmented by continent dummies. The latter may help to further control for unobserved heterogeneity across countries.

Finally, models (9) and (10) are the most comprehensive in that they include a list of labor market covariates provided by Botero et al. (2004). In particular, we use a measure related to the strictness of employment protection legislation (EPL), an index related to unemployment benefits, a variable indicating the existence of minimum wages and a variable measuring non-wage costs of labor (i.e., taxes). With the exception of EPL, none of those additional controls turns out significant.

Summarizing, we find that across most multivariate cross-sectional regressions, the effect of a 10 percentage points increase in openness lowers unemployment by about 1 percentage point (columns (8) and (10)). As with the high-quality OECD data, and presumably for the same reasons, there is no robust evidence that OLS overestimates the size of the true effect. In particular, in the more complete specification, it is hard to see any difference between IV and OLS results.

\subsubsection{Large sample: panel regressions}

Table 3 runs panel regression of five-year averages on a larger set of countries. We employ the same econometric specifications and use similar controls as in section 4.1.1. In particular, we control for the output gap in all specifications. This is important as taking five-year averages does not seem to entirely purge business cycle effects. We control for market size changes by including the logarithm of population. The institutional labor market controls are from the Fraser Institute and measure overall hiring and firing restrictions and the replacement rate. ${ }^{30}$ We also use a measure of product market regulation from the same data source. We do not have time-variant information about tax rates. Geographical variables

\footnotetext{
${ }^{30}$ The benchmark data from Botero et al. (2004) has not time dimension.
} 
and time-invariant institutional features are accounted for by country effects.

The results confirm the existence of a negative relation between real openness and the rate of unemployment. More specifically, columns (1) and (2) show the fixed (FE) and the random effects (RE) model. The Hausman test ( $p$-value of 0.291) prefers random effects. This choice has important quantitative implications in the present setup since the openness coefficient is more than twice as large in the FE model than in the RE specification. The latter indicates that an increase of openness by 10 percentage points lowers unemployment by about 0.78 percentage points. It is striking how close this latter effect comes to our cross-sectional results presented above.

The dynamic models (3) to (5) are problematic because the panel is strongly unbalanced and the number of observations over time is very small for some countries. Interestingly, in all dynamic models, the evidence for persistence in (five-year-averaged) unemployment rates is fairly low and much smaller than in the case of the OECD sample where country coverage is more homogenous and the panel is longer. The FGLS model signals a short-run openness coefficient close to the one obtained under FE in column (1); the long-run effect is almost identical. Diff-GMM produces similar results; however, the OID test ( $\mathrm{p}$-value of 0.05 ) is unsatisfyingly low so that the instrumentation strategy is doubtful in this case. The Sys-GMM model is more efficient, and can make use of more observations. The OID test and the other test statistics are fine, so that we take the Sys-GMM results as the most credible. Here, an increase in openness by 10 percentage points reduces equilibrium unemployment by about 0.57 percentage points in the short-run and by 0.84 points in the long run. Notice the quantitative similarity of these coefficients with those obtained for the smaller OECD sample discussed in section 4.1.1.

\subsection{Exports versus imports}

In the next step, we modify the benchmark regressions presented above. We substitute the measure of total (gross) openness used above by import or export openness (defined as real openness measures according to Alcalá and Ciccone, 2004). We expect that endogeneity concerns should bias the openness coefficient more strongly away from zero for imports than for exports. Moreover, by using export and import openness in the same equation, we are able to make inference on the relative strength of these two measures.

Table 4 summarizes the results. In the upper panel of the table, each cell corresponds to a separate regression where we only report the estimated coefficient and the associated robust standard error. The lower panel shows the results of one regression per column, where both measures of openness are simultaneously included. The full regression output is documented in the supplement paper. Each column corresponds to a different sample 
Table 3: Benchmark regressions: large panel

Dependent variable: Total unemployment (WDI)

Openness measure: Real openness (Alcala E Ciccone, 2004)

\begin{tabular}{|c|c|c|c|c|c|}
\hline & $\begin{array}{l}(1) \\
\mathrm{FE}\end{array}$ & $\begin{array}{l}(2) \\
\mathrm{RE}\end{array}$ & $\begin{array}{c}(3) \\
\text { FGLS }\end{array}$ & $\begin{array}{c}(4) \\
\text { Diff-GMM }\end{array}$ & $\begin{array}{c}(5) \\
\text { Sys-GMM }\end{array}$ \\
\hline Total trade openness & $\begin{array}{c}-0.223^{* * *} \\
(0.064)\end{array}$ & $\begin{array}{c}-0.078^{* * *} \\
(0.020)\end{array}$ & $\begin{array}{c}-0.217^{* * *} \\
(0.023)\end{array}$ & $\begin{array}{c}-0.174^{* *} \\
(0.075)\end{array}$ & $\begin{array}{c}-0.057^{*} \\
(0.03)\end{array}$ \\
\hline Lag. dep. var. & & & $\begin{array}{l}0.106^{* *} \\
(0.047)\end{array}$ & $\begin{array}{c}0.228^{*} \\
(0.130)\end{array}$ & $\begin{array}{c}0.319^{*} \\
(0.171)\end{array}$ \\
\hline Pop (ln) & $\begin{array}{c}-5.337 \\
(6.987)\end{array}$ & $\begin{array}{r}-0.584^{*} \\
(0.306)\end{array}$ & $\begin{array}{l}5.202^{* *} \\
(2.119)\end{array}$ & $\begin{array}{c}-2.194 \\
(1.544)\end{array}$ & $\begin{array}{c}-0.635 \\
(0.843)\end{array}$ \\
\hline LMR (index) & $\begin{array}{c}0.638^{*} \\
(0.372)\end{array}$ & $\begin{array}{c}0.448^{*} \\
(0.248)\end{array}$ & $\begin{array}{l}0.546^{* * *} \\
(0.101)\end{array}$ & $\begin{array}{c}0.414 \\
(0.323)\end{array}$ & $\begin{array}{c}0.660^{*} \\
(0.400)\end{array}$ \\
\hline Unemployment benefits (index) & $\begin{array}{c}0.077 \\
(0.160)\end{array}$ & $\begin{array}{c}0.128 \\
(0.141)\end{array}$ & $\begin{array}{l}0.210^{* * *} \\
(0.044)\end{array}$ & $\begin{array}{c}0.086 \\
(0.163)\end{array}$ & $\begin{array}{c}0.110 \\
(0.150)\end{array}$ \\
\hline PMR (index) & $\begin{array}{c}-0.227^{*} \\
(0.133)\end{array}$ & $\begin{array}{c}-0.126 \\
(0.127)\end{array}$ & $\begin{array}{c}-0.253^{* * *} \\
(0.055)\end{array}$ & $\begin{array}{c}-0.252 \\
(0.160)\end{array}$ & $\begin{array}{c}-0.147 \\
(0.155)\end{array}$ \\
\hline Output gap (\%) & $\begin{array}{c}-15.88^{* * *} \\
(5.658)\end{array}$ & $\begin{array}{c}-19.43^{* * *} \\
(5.736)\end{array}$ & $\begin{array}{c}-21.84^{* * *} \\
(3.259)\end{array}$ & $\begin{array}{r}-20.84^{*} \\
(10.88)\end{array}$ & $\begin{array}{c}-18.76 \\
(12.23)\end{array}$ \\
\hline $\mathrm{R}^{2}$ (within) & 0.291 & 0.243 & & & \\
\hline $\mathrm{R}^{2}$ (overall) & 0.042 & 0.132 & & & \\
\hline $\mathrm{R}^{2}$ (between) & 0.064 & 0.116 & & & \\
\hline Hausman & 0.2 & & & & \\
\hline OID test & & & & 0.046 & 0.367 \\
\hline $\operatorname{AR}(1)$ & & & & 0.039 & 0.029 \\
\hline $\operatorname{AR}(2)$ & & & & 0.329 & 0.771 \\
\hline
\end{tabular}

Robust Standard errors in parentheses, ${ }^{*}$ significant at $10 \%,{ }^{* *}$ significant at $5 \%,{ }^{* * *}$ significant at 1\%. All variables averaged over 5 year periods between $1971-2005$ in order to net out business cycle effects. Number of observations $\mathrm{N}=186$ (77 countries, 5 -year periods; data averaged). Panel is strongly unbalanced due to missing observations (186 five year averages available). Dependent variable is World development indicators total unemployment. Data on labor and product market regulation from Fraser institute. All models control for unobserved country- and period effects. FGLS allows for heteroscedastic errors. First lag of dependent variable used for Feasible Least Square and Generalized Methods of Moments regressions. Diff- and Sys-GMM estimators are valid if i) OID test does not reject the H0 (H0: overidentifying restrictions are valid) and ii) if test on $\mathrm{AR}(1)$ is positive and negative on $\operatorname{AR}(2)$ (H0: no autocorrelation). Openness, output gap and LMR treated as endogenous in the GMM regressions. Maximum number of lags used as instruments equals one (19 instruments for diff-GMM and 31 instruments for sys-GMM). Constant estimated but not reported. 
and/or econometric specification. Coefficients pertaining to the dynamic Sys-GMM model are long-run effects.

Row $\mathbf{i}$ is a memo item and replicates information contained in Tables 1 and 2. Rows ii and iii correspond to two separate regressions with real import openness and export openness the interesting covariate. We find that the effect of import openness in the nonIV equation $(-0.177)$ is algebraically larger than in the sys-GMM equation $(-0.1)$, where endogeneity concerns should be absent. In the case of export openness, the comparison of coefficients yields the opposite picture $(-0.050$ versus -0.138$)$. The difference between import and export openness is much smaller for the IV regressions than for the non-IV ones. These results suggest that the endogeneity bias has opposite sign for imports and exports: non-IV methods exaggerate the importance of imports on unemployment and underestimate the role of exports. As discussed above, the reason may be that adverse unemployment shocks trigger protectionist policy reactions that curb imports but boost exports.

In the large cross-section, OLS estimates are probably more strongly affected by measurement bias, which is likely to be similar in importance across imports and exports, than by endogeneity. The IV results show that estimated coefficients differ by less than the OLS coefficients and the bias is larger for imports than for exports. Hence, while this evidence is weaker than for the OECD panel, it is still consistent with the view that endogeneity biases are of opposite sign.

The lower panel in Table 4 shows results when export and import openness are simultaneously included into the same regression. Since the two variables are strongly correlated, identification of their partial effects is difficult. Moreover, in the case of the cross-section, simultaneous instrumentation of exports and imports by very similar instruments yields weak results. Across samples and methods, the estimates suggest that import openness is more robustly related to the equilibrium rate of unemployment. The estimated sign is usually negative, while it is positive for export openness. ${ }^{31}$ This is an interesting-if tentative-finding. It is in line with the view that import competition weeds out inefficient firms, which strengthens average productivity and therefore lowers long-run unemployment, while additional export opportunities may reduce the bite of the selection effect and therefore shelter inefficient firms. We present extensive robustness checks for these results below.

\footnotetext{
${ }^{31}$ The large-panel is an exception. However, we do not want to emphasize this result due to the problems discussed in section 4.1.3.
} 
Table 4: Exports versus imports

Dependent variable: Total unemployment (OECD and WDI)

Openness measure: Real openness (Alcala \&3 Ciccone, 2004)

\begin{tabular}{|c|c|c|c|c|c|c|}
\hline & \multicolumn{2}{|c|}{ OECD panel } & \multicolumn{2}{|c|}{ Large cross section } & \multicolumn{2}{|c|}{ Large panel } \\
\hline & (1) & $(2)$ & $(3)$ & (4) & $(5)$ & (6) \\
\hline & $\mathrm{FE} / \mathrm{RE}$ & Sys-GMM & OLS & IV & $\mathrm{FE} / \mathrm{RE}$ & Sys-GMM \\
\hline \multirow[t]{2}{*}{ i: Total trade } & $\begin{array}{c}-0.072^{* * *} \\
(0.018)\end{array}$ & $\begin{array}{c}-0.116^{* *} \\
(0.049)\end{array}$ & $\begin{array}{c}-0.081^{* * *} \\
(0.028)\end{array}$ & $\begin{array}{c}-0.099^{* *} \\
(0.048)\end{array}$ & $\begin{array}{c}-0.078^{* * *} \\
(0.020)\end{array}$ & $\begin{array}{r}-0.084^{*} \\
(0.044)\end{array}$ \\
\hline & \multicolumn{6}{|c|}{$\underline{\text { Separate inclusion of import and export openness }}$} \\
\hline ii: Import & $\begin{array}{c}-0.177^{* * *} \\
(0.040)\end{array}$ & $\begin{array}{l}-0.1^{*} \\
(0.054)\end{array}$ & $\begin{array}{c}-0.084^{* * *} \\
(0.030)\end{array}$ & $\begin{array}{c}-0.107^{* *} \\
(0.052)\end{array}$ & $\begin{array}{c}-0.081^{* * *} \\
(0.021)\end{array}$ & $\begin{array}{c}-0.078 \\
(0.055)\end{array}$ \\
\hline \multirow[t]{2}{*}{ iii: Export } & $\begin{array}{c}-0.050^{* * *} \\
(0.016)\end{array}$ & $\begin{array}{c}-0.138^{* * *} \\
(0.051)\end{array}$ & $\begin{array}{c}-0.077^{* * *} \\
(0.026)\end{array}$ & $\begin{array}{c}-0.093^{* *} \\
(0.045)\end{array}$ & $\begin{array}{c}-0.178^{* * *} \\
(0.064)\end{array}$ & $\begin{array}{c}-0.089^{* * *} \\
(0.037)\end{array}$ \\
\hline & \multicolumn{6}{|c|}{$\underline{\text { Simultaneous inclusion of import and export openness }}$} \\
\hline Import & $\begin{array}{c}-0.244^{* *} \\
(0.075)\end{array}$ & $\begin{array}{c}-0.491 \\
(0.429)\end{array}$ & $\begin{array}{c}0.108 \\
(0.185)\end{array}$ & $\begin{array}{c}-0.871 \\
(2.541)\end{array}$ & $\begin{array}{c}-0.033 \\
(0.067)\end{array}$ & $\begin{array}{c}0.222 \\
(0.139)\end{array}$ \\
\hline Export & $\begin{array}{c}0.120^{*} \\
(0.056)\end{array}$ & $\begin{array}{c}0.344 \\
(0.381)\end{array}$ & $\begin{array}{c}-0.170 \\
(0.162)\end{array}$ & $\begin{array}{c}0.666 \\
(2.166)\end{array}$ & $\begin{array}{c}-0.043 \\
(0.061)\end{array}$ & $\begin{array}{c}-0.289^{* *} \\
(0.118)\end{array}$ \\
\hline
\end{tabular}

In row i - iii, each cell represents one regression. For simultaneous import and export openness regressions, we report coefficients for both measures in one column. Openness coefficients reported only. Robust standard errors in parentheses, ${ }^{*}$ significant at $10 \%,{ }^{* *}$ significant at $5 \%,{ }^{* * *}$ significant at $1 \%$. All variables averaged over 5-year periods between 1980 - 2003 (OECD panel), 1971 - 2005 (large panel) and over the whole period 1990 - 2006 (large cross section) to net out business cycles. Long-run effects reported for sys-GMM regressions. Total unemployment rate (OECD and WDI) used as dependent variable. An improved Frankel \& Romer (1999) instrument used for the IV regressions. FE/RE: fixed or random effects model selected according to Hausman test (Except for real import openness in the OECD panel and real export openness in the large panel, RE preferred for all regressions). For further details see Tables 1,2 , and 3 . 


\section{Additional results}

In this section we present a number of additional results. First, we explore the channels through which openness affects the equilibrium rate of unemployment. Second, we search for interactions between openness and other variables, most importantly labor market institutions. And third, we discuss a large array of robustness checks.

\subsection{Through which channels does openness affect unemployment?}

In this section we scan potential channels through which openness might affect unemployment. We check Total Factor Productivity, capital to labor ratio, and various labor and product market institutions for both, the OECD and the large cross section. Table 5 reports only the variables of interest. Full regression details can be found in the supplement paper. The underlying models are similar to those presented in Tables 1 and 2 with the following modifications. In column (1) we regress the unemployment rate on the respective channel variable, but do not include openness itself. All other covariates are those presented in the benchmark models. In column (2) we use the channel variable as the dependent variable and include an aggregate measure of trade openness into the list of covariates. Column (3) reverts to the standard specification with the rate of unemployment as the dependent variable, but includes both openness and the respective channel variable into the regression.

The role of TFP. We start with total factor productivity (TFP). In search-theoretic explanations of equilibrium unemployment, it is possible that firms with higher productivity find it more attractive to post vacancies; see Epifania and Gancia (2005) or Felbermayr, Prat and Schmerer (2008). In the latter example, more openness forces unproductive firms to quit and allows more productive ones to expand. The average firm's productivity increases, its revenue per match relative to the costs of vacancy creation goes up, and so do its incentives to create jobs. Hence, increased openness leads to lower equilibrium unemployment in the long-run through higher productivity.

For the OECD panel, we construct a proxy for TFP by following the procedure in Benhabib and Spiegel (2005), who apply the perpetual inventory method to back out estimates for capital and then compute TFP as the Solow residual. We use the original estimates published in Benhabib and Spiegel (2005) for the large cross-section. Column (1) in the upper panel in Table 5 shows that countries with higher TFP have lower unemployment rates. ${ }^{32}$ Note that this effect cannot be driven by business cycle variation since we work

\footnotetext{
${ }^{32}$ Pissarides and Vallanti (2007) propose theoretical and empirical results on the relation between TFP
} 
with averages over 5-year averages, and we have included year dummies and a measure of the output gap into the regressions. The effect is fairly strong in the OECD panel: a one percent increase in TFP lowers the equilibrium rate of unemployment by about 0.4 percentage points. Going from the sample mean of TFP to the highest realization, the decrease in unemployment is about 7 percentage points. In the large cross-section, TFP is important, too. A one percent increase in TFP lowers unemployment by about 0.04 percentage points. However, due to greater variance of TFP measures in the larger cross-section, moving from the sample mean to the highest realization of TFP yields an unemployment reduction of about 2.8 percentage points. This effect is fairly robust when-in the OECD panel-we use alternative definitions of unemployment rates (youth unemployment, prime age unemployment) or-in the large cross-section-unemployment data from ILO or the CIA is used instead of that reported by the World Bank.

Column (2) in the first panel shows the effect of real openness on the log of TFP. The results are broadly in line with Alcalá and Ciccone, who use a somewhat different definition of TFP for the year of 1985 in their cross-sectional analysis. Doubling real openness from the sample mean (about 35 for the OECD panel and 30 in the large cross section) leads to an increase in TFP by about 7 percent in the OECD panel and by about 24 percent in the large cross-section.

Column (3) uses both, the log of TFP and real openness in the same unemployment regression. In the OECD sample, the coefficient on TFP turns out negative and statistically significant, with a coefficient similar to the one estimated in column (1). The openness measure is now insignificant, which is in contrast to our benchmark results presented in Table 1. Hence, the effect of openness goes through TFP, and there is no evidence (even if the sign is correctly estimated) that openness directly lowers the equilibrium rate of unemployment. In the large cross-section, the log of TFP and openness both turn out insignificant, but a F-tests strongly rejects the Null that both coefficients are jointly zero. Our results therefore suggest that openness affects unemployment mostly trough its beneficial effect on TFP.

The role of factor proportions. Next, we ask whether openness affects unemployment through a capital accumulation effect. The hypothesis is that a higher degree of openness adds incentives for capital accumulation which could increase the marginal value product of labor and thereby foster job creation. Indeed, in both samples, a higher capital to labor ratio $(K / L)$ turns out to be negatively related to equilibrium unemployment. There is no evidence that trade openness boosts capital accumulation. Using openness and $K / L$ jointly in a single regression, we find negative signs on both variables (in line with the hypothesis),

and unemployment that are consistent with our findings. 
Table 5: Through which channels does openness affect unemployment?

\begin{tabular}{|c|c|c|c|c|c|c|}
\hline & \multicolumn{3}{|c|}{ OECD panel } & \multicolumn{3}{|c|}{ Large cross section } \\
\hline & $(1)$ & $(2)$ & $(3)$ & $(1)$ & $(2)$ & $(3)$ \\
\hline & $\mathrm{FE} / \mathrm{RE}$ & $\mathrm{FE} / \mathrm{RE}$ & $\mathrm{FE} / \mathrm{RE}$ & IV & IV & IV \\
\hline I Dep. var. $\Rightarrow$ & $\mathrm{u}$ & $\log$ TFP & $\mathrm{u}$ & $\mathrm{u}$ & $\log \mathrm{TFP}^{A)}$ & $\mathrm{u}$ \\
\hline $\log$ TFP & $\begin{array}{l}-31.419^{* * *} \\
(7.484)\end{array}$ & & $\begin{array}{l}-28.803^{* * *} \\
(8.776)\end{array}$ & $\begin{array}{l}-4.231^{* * *} \\
(1.471)\end{array}$ & & $\begin{array}{c}-2.244 \\
(3.599)\end{array}$ \\
\hline $\begin{array}{l}\text { Total trade openness } \\
\text { (real) }\end{array}$ & & $\begin{array}{l}0.002^{* *} \\
(0.001)\end{array}$ & $\begin{array}{r}-0.023 \\
(0.025)\end{array}$ & & $\begin{array}{l}0.008^{* * *} \\
(0.002)\end{array}$ & $\begin{array}{c}-0.042 \\
(0.067)\end{array}$ \\
\hline II Dep. var. $\Rightarrow$ & $\mathrm{u}$ & $\mathrm{K} / \mathrm{L}$ & $\mathrm{u}$ & $\mathrm{u}$ & $\mathrm{K} / \mathrm{L}$ & $\mathrm{u}$ \\
\hline $\mathrm{K} / \mathrm{L}$ & $\begin{array}{l}-0.560^{* *} \\
(0.227)\end{array}$ & & $\begin{array}{l}-0.603^{* * *} \\
(0.222)\end{array}$ & $\begin{array}{l}-0.438^{* * *} \\
(0.151)\end{array}$ & & $\begin{array}{l}-0.273^{* * *} \\
(0.133)\end{array}$ \\
\hline $\begin{array}{l}\text { Total trade openness } \\
\text { (real) }\end{array}$ & & $\begin{array}{c}-0.023 \\
(0.018)\end{array}$ & $\begin{array}{l}-0.075^{* * *} \\
(0.019)\end{array}$ & & $\begin{array}{c}0.043 \\
(0.043)\end{array}$ & $\begin{array}{r}-0.089^{*} \\
(0.051)\end{array}$ \\
\hline III Dep. var. $\Rightarrow$ & $\mathrm{u}$ & Wage dis. & $\mathrm{u}$ & $\mathrm{u}$ & Wage dis. $\left.{ }^{B}\right)$ & $\mathrm{u}$ \\
\hline Wage Distortion & $\begin{array}{l}0.111^{* * *} \\
(0.026)\end{array}$ & & $\begin{array}{l}0.110^{* * *} \\
(0.025)\end{array}$ & $\begin{array}{c}1.579 \\
(1.611)\end{array}$ & & $\begin{array}{c}1.659 \\
(1.405)\end{array}$ \\
\hline $\begin{array}{l}\text { Total trade openness } \\
\text { (real) }\end{array}$ & & $\begin{array}{l}-0.458^{* * *} \\
(0.124)\end{array}$ & $\begin{array}{l}-0.072^{* * *} \\
(0.018)\end{array}$ & & $\begin{array}{c}-0.001 \\
(0.003)\end{array}$ & $\begin{array}{c}-0.099^{* *} \\
(0.048)\end{array}$ \\
\hline IV Dep. var. $\Rightarrow$ & $\mathrm{u}$ & PMR & $\mathrm{u}$ & $\mathrm{u}$ & $\mathrm{PMR}^{C)}$ & $\mathrm{u}$ \\
\hline PMR & $\begin{array}{c}0.746 \\
(0.491)\end{array}$ & & $\begin{array}{c}0.858^{*} \\
(0.463)\end{array}$ & $\begin{array}{c}0.329 \\
(0.285)\end{array}$ & & $\begin{array}{l}0.028 \\
(0.338)\end{array}$ \\
\hline $\begin{array}{l}\text { Total trade openness } \\
\text { (real) }\end{array}$ & & $\begin{array}{c}0.010 \\
(0.014)\end{array}$ & $\begin{array}{l}-0.076^{* * *} \\
(0.018)\end{array}$ & & $\begin{array}{l}0.006 \\
(0.021)\end{array}$ & $\begin{array}{c}-0.102^{* *} \\
(0.047)\end{array}$ \\
\hline V Dep. var. $\Rightarrow$ & $\mathrm{u}$ & EPL & $\mathrm{u}$ & $\mathrm{u}$ & EPL & $\mathrm{u}$ \\
\hline EPL & $\begin{array}{c}-0.642 \\
(0.541)\end{array}$ & & $\begin{array}{c}-0.533 \\
(0.540)\end{array}$ & $\begin{array}{c}4.499 \\
(2.745)\end{array}$ & & $\begin{array}{l}5.515^{* *} \\
(2.553)\end{array}$ \\
\hline $\begin{array}{l}\text { Total trade openness } \\
\text { (real) }\end{array}$ & & $\begin{array}{c}0.004 \\
(0.007)\end{array}$ & $\begin{array}{l}-0.072^{* * *} \\
(0.018)\end{array}$ & & $\begin{array}{l}-0.000 \\
(0.002)\end{array}$ & $\begin{array}{l}-0.099^{* *} \\
(0.048)\end{array}$ \\
\hline
\end{tabular}

Each column in each cell represents one regression. Openness and channel variable coefficients reported only. As channel variables we use the capital to labor ratio, Total Factor Productivity, Product Market Regulations and Labor Market Regulations. For the large sample we use A) $\log$ TFP provided by Benhabib and Spiegel (2005), B) unemployment benefits as proxy for wage distortion and C) PMR from the Fraser data base. In (1) we regress openness on unemployment, in (2) we regress the channel variable on openness, and in (3) we regress openness and the channel variable on unemployment. Robust standard errors in brackets, * significant at $10 \%$, ** significant at $5 \%$ and $* * *$ significant at $1 \%$. For the OECD panel we run benchmark type fixed- random effects regressions. FE/RE: fixed or random effects model selected according to Hausman test (RE preferred for all regressions with unemployment as dependent variable (1) and (3) and FE preferred for all regressions where we use openness as dependent variable (2)). For the large cross section we run benchmark type IV regressions. An improved Frankel \& Romer (1999) instrument used as instrument for the IV regressions. 
but relative to the benchmark results in Tables 1 and 2 the estimated openness coefficients are hardly affected.

The role of institutions. One may conjecture that trade openness puts pressure on policymakers to redesign institutions and policies such that they are more efficient. In columns (2) in panels III, IV, and V, we regress the degree of wage distortion, an index of product market regulation (strongly related to the fierceness of competition) and an index of employment protection legislation (EPL) on real openness. Only in the case of wage distortion and in the OECD panel do we find any significant effect: openness reduces the sum of replacement rate plus labor taxes such that a ten percentage point increase in openness lowers the distortion by about 5 percentage points. The sign of the effect is negative in the large cross-section, but insignificant. There is no evidence that openness lowers product market regulation.

We have conducted a number of robustness checks on Table 5 (see the supplement paper) which confirm that trade affects unemployment through its effect on TFP and capital accumulation; other potential channels do not seem to matter.

\subsection{Interaction terms}

It is natural to investigate variables that condition the effect of openness on the structural rate of unemployment. For example, the Heckscher-Ohlin model with search frictions (Davidson and Matusz, 1999) predicts that trade liberalization should increase unemployment in capital-rich countries and reduce it in labor-abundant ones. Other models and the political debate suggest that the effect should depend on labor market institutions such that countries with inefficient institutions suffer from liberalization of international trade while those with efficient institutions benefit. Table 6 includes a number of interaction terms into our benchmark OECD panel, where $Z$ is the conditioning variable, and $T$ is short-hand for trade openness. The table limits attention to the fixed and random effects specifications, always reporting the specification recommended by the Hausman test. It does not report GMM estimates, which are problematic because of substantial uncertainty about the correct lag structure in the instrument matrix. We report these results together with the cross-sectional analysis in the supplement paper. In any case, different methods yield very similar results.

None of the interactions presented in Table 6 is statistically significant. Column (1) uses the aggregate capital-labor ratio; Heckscher-Ohlin arguments would suggest a positive sign. The evidence confirms the sign but the estimate is not distinguishable from zero. Dutt et al. (2009) present a model and more extensive evidence on this point. Alternatively, 
Table 6: Do labor market institutions condition the effect of openness on unemployment (OECD panel)?

\begin{tabular}{|c|c|c|c|c|c|c|c|c|}
\hline \multicolumn{9}{|c|}{$\begin{array}{l}\text { Dependent variable: Total unemployment (WDI) } \\
\text { Openness measure: Real openness (Alcala \& Ciccone, 2004) }\end{array}$} \\
\hline & (1) & $(2)$ & (3) & (4) & $(5)$ & (6) & $(7)$ & $(8)$ \\
\hline & $\mathrm{FE} / \mathrm{RE}$ & $\mathrm{FE} / \mathrm{RE}$ & $\mathrm{FE} / \mathrm{RE}$ & $\mathrm{FE} / \mathrm{RE}$ & $\mathrm{FE} / \mathrm{RE}$ & $\mathrm{FE} / \mathrm{RE}$ & $\mathrm{FE} / \mathrm{RE}$ & $\mathrm{FE} / \mathrm{RE}$ \\
\hline Interaction variable $(Z)$ & $\mathrm{K} / \mathrm{L}$ & TFP & $\begin{array}{l}\text { Replace. } \\
\text { rate }\end{array}$ & $\begin{array}{c}\text { Tax } \\
\text { wedge }\end{array}$ & $\begin{array}{l}\text { High } \\
\text { corp. }\end{array}$ & $\begin{array}{l}\text { Union } \\
\text { density }\end{array}$ & PMR & EPL \\
\hline Total trade openness $(T)$ & $\begin{array}{c}-0.107^{* *} \\
(0.052)\end{array}$ & $\begin{array}{r}-0.102 \\
(0.580)\end{array}$ & $\begin{array}{r}-0.048 \\
(0.054)\end{array}$ & $\begin{array}{c}-0.097^{* *} \\
(0.046)\end{array}$ & $\begin{array}{r}-0.057 \\
(0.065)\end{array}$ & $\begin{array}{c}-0.125^{* *} \\
(0.055)\end{array}$ & $\begin{array}{c}-0.074^{* *} \\
(0.033)\end{array}$ & $\begin{array}{r}-0.065^{*} \\
(0.037)\end{array}$ \\
\hline$Z \times T$ & $\begin{array}{c}0.035 \\
(0.049)\end{array}$ & $\begin{array}{c}0.266 \\
(2.101)\end{array}$ & $\begin{array}{l}-4.972 \\
(13.438)\end{array}$ & $\begin{array}{c}0.156 \\
(0.155)\end{array}$ & $\begin{array}{c}-0.797 \\
(5.286)\end{array}$ & $\begin{array}{c}0.148 \\
(0.127)\end{array}$ & $\begin{array}{c}0.266 \\
(0.981)\end{array}$ & $\begin{array}{c}0.001 \\
(0.238)\end{array}$ \\
\hline$Z$ & $\begin{array}{c}-0.081^{* * *} \\
(0.030)\end{array}$ & $\begin{array}{r}-23.442^{*} \\
(13.969)\end{array}$ & $\begin{array}{c}0.059 \\
(0.047)\end{array}$ & $\begin{array}{c}0.188^{* *} \\
(0.075)\end{array}$ & $\begin{array}{c}-0.706 \\
(1.562)\end{array}$ & $\begin{array}{c}-0.069 \\
(0.051)\end{array}$ & $\begin{array}{c}0.807 \\
(0.617)\end{array}$ & $\begin{array}{r}-1.464 \\
(1.027)\end{array}$ \\
\hline Observations & 95 & 95 & 100 & 100 & 100 & 100 & 100 & 100 \\
\hline $\mathrm{R}^{2}$ (within) & 0.669 & 0.659 & 0.661 & 0.665 & 0.662 & 0.667 & 0.662 & 0.661 \\
\hline $\mathrm{R}^{2}$ (overall) & 0.577 & 0.557 & 0.418 & 0.419 & 0.413 & 0.431 & 0.412 & 0.327 \\
\hline $\mathrm{R}^{2}$ (between) & 0.547 & 0.540 & 0.329 & 0.329 & 0.322 & 0.344 & 0.320 & 0.416 \\
\hline
\end{tabular}

one may argue that high productivity countries benefit from trade liberalization while less productive ones suffer. This hypothesis does not bear out in the data, neither. Columns (3) to (8) use interactions of institutional variables such as the replacement rate, the tax wedge, the degree of corporatism, union density, product market regulation (PMR), or the degree of employment protection legislation (EPL). Standard errors to the estimated effects are always very high, so that we cannot reject the Null that all these conditioning effects are statistically irrelevant.

\subsection{Additional robustness checks.}

In this section, we report a number of robustness checks whose details are reported in the supplement paper.

Alternative openness measures. In the main body of this paper, we use the real openness measure of Alcalá and Ciccone (2004) as our preferred indicator of trade openness. We have seen that the effect of trade on unemployment is likely to run through improved aggregate productivity. Since productivity changes are likely to have a sector bias, we have to care about the Balassa-Samuelson effect. The measure of real openness accounts for this. Nonetheless, the growth-openness literature uses an uncorrected measure that we 
call current price openness (Alcalá and Ciccone use the term openness tout court). ${ }^{33}$

The upper part of Table 7 reports results for different openness measures. The focus is on current price openness. Only openness coefficients and their standard errors are reported; details are relegated to the supplement paper. We look at the OECD panel, the large cross-section, and the large panel and compare models that control for endogeneity and those that do not. The upper panel uses either total openness or export or import openness separately in the regressions. We also try the constant price openness measure reported in the Penn World Tables and an indicator that draws only on merchandise trade (i.e, excluding services). Across all these specifications, we do not find a single positive coefficient. Coefficient estimates are often algebraically bigger than in our benchmark results, so that the choice of the openness measure does have an influence on the quantitative interpretation of results. Some of the coefficients from the large panel are insignificant statistically, but for reasons detailed above we do not want to over emphasize these findings. Hence, we confirm our general conclusion that openness certainly does not increase unemployment in the long-run. Comparing with the results reported in Table 4, we find that the real openness measure performs better in terms of stability of coefficients across specifications. Discrepancies between export and import openness measures are also smaller so that the robustness checks confirm the superiority of the real openness indicator over alternative options.

Log unemployment. There is no apparent consensus in the labor market literature as to whether unemployment regressions have to be run with the dependent variable in logs or in levels. Almost all equations discussed in Bassanini and Duval (2009) are in levels; the recent paper by Costain and Reiter (2008) uses logs. In the present setup, results are largely independent of this choice, as can be seen from the middle part of Table 7, where we keep estimation strategies and samples identical to those used in the upper part but just use the log of unemployment as the dependent variable. While significance of the openness coefficient may be lost in some cases, there is no evidence-not in a single regression-that openness increases unemployment in the long run.

Alternative unemployment measures and data sources. Our benchmark regressions use total unemployment rates provided by the OECD, and in the larger samples, data reported by the World Bank in their World Indicator Data base. There are substantial concerns about data quality, in particular in samples that include developing countries. Moreover, even OECD countries have very different approaches to dealing with employment issues for workers at the start or the end of their professional careers. We deal with

\footnotetext{
${ }^{33}$ See section 2.1.2 for a more detailed discussion of different openness measures.
} 
this problem by running our regressions using alternative unemployment measures.

For the OECD we substitute the total unemployment rate by prime age and youth unemployment but use the Alcalá and Ciccone real openness measure.

\section{Table 7: Robustness checks}

\begin{tabular}{|c|c|c|c|c|c|c|}
\hline \multicolumn{7}{|c|}{ Dependent variable: Total unemployment (OECD and WDI) } \\
\hline \multirow[b]{2}{*}{ Openness measure $\Downarrow$} & \multicolumn{2}{|c|}{ OECD panel } & \multicolumn{2}{|c|}{ Large cross section } & \multicolumn{2}{|c|}{ Large panel } \\
\hline & $\begin{array}{c}(1) \\
\mathrm{FE} / \mathrm{RE}\end{array}$ & $\begin{array}{c}(2) \\
\text { Sys-GMM }\end{array}$ & $\begin{array}{c}(3) \\
\text { OLS }\end{array}$ & $\begin{array}{l}\text { (4) } \\
\text { IV }\end{array}$ & $\begin{array}{c}(5) \\
\mathrm{FE} / \mathrm{RE}\end{array}$ & $\begin{array}{c}(6) \\
\text { Sys-GMM }\end{array}$ \\
\hline \multicolumn{7}{|c|}{ Current price openness } \\
\hline i: Total trade & $\begin{array}{c}-0.059^{* *} \\
(0.023)\end{array}$ & $\begin{array}{c}-0.235^{* *} \\
(0.116)\end{array}$ & $\begin{array}{c}-0.026 \\
(0.017)\end{array}$ & $\begin{array}{r}-0.123^{*} \\
(0.066)\end{array}$ & $\begin{array}{c}-0.032^{* *} \\
(0.014)\end{array}$ & $\begin{array}{c}-0.054 \\
(0.036)\end{array}$ \\
\hline ii: Import & $\begin{array}{c}-0.081^{* * *} \\
(0.027)\end{array}$ & $\begin{array}{c}-0.257^{* *} \\
(0.116)\end{array}$ & $\begin{array}{c}-0.023 \\
(0.019)\end{array}$ & $\begin{array}{r}-0.140^{*} \\
(0.077)\end{array}$ & $\begin{array}{c}-0.029^{* *} \\
(0.014)\end{array}$ & $\begin{array}{c}-0.03 \\
(0.042)\end{array}$ \\
\hline iii: Export & $\begin{array}{r}-0.039^{*} \\
(0.021)\end{array}$ & $\begin{array}{r}-0.183^{*} \\
(0.101)\end{array}$ & $\begin{array}{r}-0.028^{*} \\
(0.016)\end{array}$ & $\begin{array}{c}-0.110^{*} \\
(0.057)\end{array}$ & $\begin{array}{c}-0.032^{* *} \\
(0.013)\end{array}$ & $\begin{array}{c}-0.074^{* *} \\
(0.032)\end{array}$ \\
\hline \multicolumn{7}{|c|}{ Constant price openness } \\
\hline iv: Total trade & $\begin{array}{c}-0.078^{* * *} \\
(0.018)\end{array}$ & $\begin{array}{r}-0.132^{*} \\
(0.074)\end{array}$ & $\begin{array}{c}-0.027 \\
(0.018)\end{array}$ & $\begin{array}{c}-0.130^{*} \\
(0.072)\end{array}$ & $\begin{array}{c}-0.042^{* * *} \\
(0.015)\end{array}$ & $\begin{array}{c}-0.039 \\
(0.036)\end{array}$ \\
\hline \multicolumn{7}{|c|}{ Merchandize trade openness } \\
\hline v: Total trade & $\begin{array}{c}-0.046 \\
(0.034)\end{array}$ & $\begin{array}{c}-0.187^{* *} \\
(0.09)\end{array}$ & $\begin{array}{c}-0.013 \\
(0.010)\end{array}$ & $\begin{array}{r}-0.073^{*} \\
(0.040)\end{array}$ & $\begin{array}{c}-0.029^{* *} \\
(0.014)\end{array}$ & $\begin{array}{r}-0.065^{*} \\
(0.035)\end{array}$ \\
\hline \multicolumn{7}{|c|}{ Log total unemployment and real total trade openness } \\
\hline vi: Total trade & $\begin{array}{c}-0.006^{* *} \\
(0.003)\end{array}$ & $\begin{array}{c}-0.014^{*} \\
(0.007)\end{array}$ & $\begin{array}{c}-0.009^{* *} \\
(0.003)\end{array}$ & $\begin{array}{c}-0.009^{*} \\
(0.005)\end{array}$ & $\begin{array}{c}-0.009^{* * *} \\
(0.003)\end{array}$ & $\begin{array}{c}-0.008 \\
(0.006)\end{array}$ \\
\hline
\end{tabular}

Dependent variable: Prime/youth unemployment, total unemployment CIA/IFS/ILO definition

Openness measure: Real total trade openness (Alcala \& Ciccone, 2004)

\begin{tabular}{ccccccc}
\hline & Sys-GMM & Sys-GMM & IV & IV & Sys-GMM & \multicolumn{2}{c}{ Sys-GMM } \\
Unemployment rate & Prime & Youth & CIA & IFS & ILO & IFS \\
\hline vii: Total trade & $-0.174^{* *}$ & -0.146 & $-0.166^{* *}$ & $-0.083^{*}$ & $-0.104^{* *}$ & $-0.096^{* *}$ \\
& $(0.068)$ & $(0.130)$ & $(0.067)$ & $(0.045)$ & $(0.049)$ & $(0.041)$
\end{tabular}

In row i - vii, each cell represents one regression. Openness coefficients reported only. Robust standard errors in parentheses, ${ }^{*}$ significant at $10 \%,{ }^{* *}$ significant at $5 \%, * * *$ significant at $1 \%$. All variables averaged over 5-year periods between 1980 - 2003 (OECD panel), 1971 - 2005 (large panel) and over the whole period 1990 2006 (large cross section) to net out business cycles. Long-run effects reported for sys-GMM regressions. Total unemployment rate (OECD and WDI) used as dependent variable in row i - iv. In row vi we use prime age, youth, CIA, IFS, and ILO data for total unemployment. In row vii we use the respective ln unemployment variable. Current price openness measures used in row i - iii, constant price openness in row iv, merchandize in row v and real total trade openness in row vi and vii. An improved Frankel \& Romer (1999) instrument used for the IV regressions. FE/RE: fixed or random effects model selected according to Hausman test (RE is preferred for all regressions). For further details see Tables 1,2 , and 3. 
The first two columns in the lower part of 7 show sys-GMM estimates. For prime age unemployment openness has a stronger effect than for youth unemployment and is only marginally significant in the latter case. This is not overly surprising because youth unemployment is probably much more strongly related to institutional features of labor markets rather than to the extent of trade openness.

The remaining columns in the lower part of 7 report results for the larger cross-section and then for the larger panel, but use unemployment data from alternative data sources. Most importantly, data from the CIA leads to a much stronger effect of openness on the structural rate of unemployment. This is a robust finding, for which we present more evidence in the supplement paper. The other data sources also yield negative coefficients that are of similar size to those obtained with our preferred data base, the WDI.

\section{Conclusion}

This paper establishes an empirical regularity: trade openness does not increase structural unemployment in the long run. Quite to the contrary, in most of our regressions, we find overwhelming evidence for a beneficial effect. This finding is robust to the choice of sample, estimation strategy, and does not hinge on our particular choice of openness measure or the definition of the unemployment rate.

Our analysis draws on two long-standing research traditions: panel unemployment regressions for OECD countries, recently summarized by Nickel et al. (2005), and crosssectional analysis of the effect of trade liberalization pioneered by Frankel and Romer (1999). In all cases, we average our data and use information on the output gap in order to control for business cycle effects. We include a large host of institutional variables and of geographical controls related to the importance of domestic as compared to international trade. Whenever possible, we include country and year effects. We deal with the possible endogeneity of openness either by exploiting the time dimension of the data or by using the geography-based instrumentation strategy developed by Frankel and Romer (1999). All of our different approaches have advantages and drawbacks. However, the picture across all models is fairly stable and robust. Moreover, we have sufficient evidence to conclude that openness is causally related to lower unemployment.

We conjecture that the endogeneity bias has a different sign for imports than for exports so that the non-instrumented regressions bias the openness coefficient away from zero in the case of import openness and towards zero in the case of export openness. The reason is that policy-makers may resort to export-promoting and import-hindering policies when an economy is hit by an adverse unemployment shock. We find evidence for exactly this 
structure, which lends external credibility to our instrumentation strategy.

Our benchmark regressions make use of the Alcalá and Ciccone (2004) measure of real openness. This indicator is closely related to the usual ratio of exports plus imports over GDP, but corrects for cross-sector differences in rates of technological change, thereby dealing with the Balassa-Samuelson effect. That correction is important in the present context, since the data suggests that openness affects unemployment mainly through its beneficial impact on factor productivity.

Our results are therefore in line with theoretical work that points towards a negative effect of trade liberalization on the structural rate of unemployment. Models of this type are presented in Dutt et al. (2009) or in Felbermayr, Prat, and Schmerer (2008). The recent work by Helpman, Itshoki, and Redding (2008) is also compatible with the evidence.

Finally, it is worth noting that the present paper has a focus on long-run effects. We pay special attention to netting out business cycle disturbances. In this sense, our work is complementary to a growing number of empirical papers on the short-run implications of trade liberalization for labor markets. 


\section{References}

[1] Ades, A. And E. Glaeser. (1999), "Evidence on Growth, Increasing Returns, and the Extent of the Market", Quarterly Journal of Economics, 114(3): 1025-45.

[2] Alcalá, F. And A. Ciccone (2004), "Trade and Productivity", Quarterly Journal of Economics 119(2): 613 - 646.

[3] Alesina, A., E. Spolaore and R. Wacziarg (2000), "Economic Integration and Political Disintegration", American Economic Review 90(5): 1276-96.

[4] Arellano, M. And S. Bond (1991), "Some tests of specification for panel data: Monte Carlo evidence and an application to employment equations", The Review of Economic Studies 58: 277-97.

[5] Baker, D., A. Glyn, D. Howell And J. Schmitt (2004), "Labor Market Institutions and Unemployment : A Critical Assessment of the Cross-Country Evidence". In: Fighting Unemployment: The Limits of Free Market Orthodoxy, ed. by D. Howell. Oxford: Oxford University Press.

[6] Bassanini, A. And R. Duval (2009), "Unemployment, Institutions and Reform Complementarities: Re-Assessing the Aggregate Evidence for OECD Countries", $O x$ ford Review of Economic Policy, forthcoming.

[7] Benhabib, J. and M. Spiegel (2005), "Human Capital and Technology Diffusion', in: Aghion, P., and Durlauf, S. (eds.), Handbook of Economic Growth, volume 1, chapter 13, 935-966.

[8] Bernard, A., Redding, S. And P. Schott (2007), "Comparative. Advantage and Heterogeneous Firms", Review of Economic Studies 74: 31-66.

[9] Blanchard, O. (2006), "European Unemployment: The Evolution of Facts and Ideas", Economic Policy 21(45): 5 - 59.

[10] Blanchard, O. and F. Giavvazi (2003), "Macroeconomic effects of regulation and deregulation on product and labor markets", Quarterly Journal of Economics 118(3): 879-907.

[11] Blanchard, O. And J. Wolfers (2000),"The Role of Shocks and Institutions in the Rise of European Unemployment: The Aggregate Evidence', Economic Journal 110(462), C1-33.

[12] Blundell, R. And S. Bond (1998), "Initial conditions and moment restrictions in dynamic panel data models", Journal of Econometrics 87: 115-43. 
[13] Botero, J., S. Djankov, R. La Porta, F. López de Silanes and A. Shleifer (2004), "The Regulation of Labor." Quarterly Journal of Economics 119: 1339-1382.

[14] Boulhol, H. (2008), "Unemployment and interactions between trade and labour market institutions", CES Working papers.

[15] Brecher, R. (1974), "Minimum wage rates and the pure theory of international trade", Quarterly Journal of Economics 88: 98-116.

[16] Coe, D., and E. Helpman (1995), "International R\&D Spillovers," European Economic Review 39(5): 859-87.

[17] Costain, James S. And Michael Reiter (2008), "Business cycles, unemployment insurance, and the calibration of matching models ", Journal of Economic Dynamics and Control 32(4): 1120-1155.

[18] Davidson, C., Martin, M. And Matusz, S.J. (1988), "The structure of simple general equilibrium models with frictional unemployment", Journal of Political Economy 96(6): 1267-93.

[19] Davidson, C., Martin, M. and Matusz, S.J. (1999), "Trade and Search Generated Unemployment", Journal of International Economics 48(2): 271-99.

[20] Davidson, C. And Matusz, S.J. (2004), "International Trade and Labor Markets. Theory, Evidence and Policy Implications", Mimeo: W.E. Upjohn Institute for Employment Research, Kalamazoo, Michigan.

[21] DAvis, D. (1998), "Does European unemployment prop up American wages? National labor markets and global trade", American Economic Review 88: 478-494.

[22] Dinopoulos, E., And P. Thompson (2000), "Endogenous Growth in a CrossSection of Countries", Journal of International Economics 51(2): 335-62.

[23] Dutt, P., D. Mitra and P. Ranjan (2009), "International Trade and Unemployment: Theory and Cross-National Evidence", Journal of International Economics, forthcoming.

[24] Egger, H. And U. Kreickemeier (2009), "Firm Heterogeneity and the Labor Market Effects of Trade Liberalization", International Economic Review, forthcoming.

[25] Epifani P. and G.A. Gancia (2005), "Trade, migration and regional unemployment", Regional Science and Urban Economics 35: 625-644. 
[26] European Economic Advisory Group at CESifo (2008), "The EAAG Report on the European Economy 2008: Europe in a Globalizing World", CESifo Munich.

[27] Felbermayr, G. and J. Prat (2009), "Product Market Regulation, Firm Selection and Unemployment", Journal of the European Economic Association, forthcoming.

[28] Felbermayr G., J. Prat and H.-J. Schmerer (2008), "Globalization and Labor Market Outcomes: Wage Bargaining, Search Frictions, and Firm Heterogeneity", IZA working paper No. 3363.

[29] Frankel, J. A. And D. Romer (1999), "Does Trade Cause Growth?", American Economic Review 89(3): 379-399.

[30] Helpman, E. and O. Itskhoki (2007), "Labor Market Rigidities, Trade and Unemployment", NBER working paper No. 13365.

[31] Helpman, E., O. Itskhoki and S. Redding (2009), "Wages, Unemployment and Inequality with Heterogeneous Firms and Workers", NBER working paper No. 14122.

[32] Immervoll, H., H. Kleven, C. Kreiner and E. Saez (2007), "Welfare Reform in European Countries: A Microsimulation Analysis", Economic Journal, 117: 1-44.

[33] Krugman, P. (1993),"The Narrow and Broad Arguments for Free Trade", American Economic Review 83(2): 362 - 366.

[34] Melitz, M. (2003), "The impact of trade on intraindustry reallocations and aggregate industry productivity", Econometrica 71, 1695-1725.

[35] Nickell, S. (1997), "Unemployment and Labor Market Rigidities: Europe versus North America", Journal of Economic Perspectives 11(3): 55 - 74.

[36] Nickell, S., L. Nunziata and W. Ochel (2005), "Unemployment in the OeCD Since the 1960s. What Do We Know?", Economic Journal 115(500): 1-27.

[37] Noguer, M., Siscart M. (2005), "Trade raises income: a precise and robust result", Journal of International Economics 65(2): 447-460.

[38] Pissarides, C.A., Vallanti G. (2004), "The Impact of TFP Growth on Steady State Unemployment", International Economic Review 48(2): 607-640.

[39] Rodriguez, F. And D. Rodrik (2000), "Trade policy and economic growth: a skeptic's guide to the crossnational evidence". In: Ben, B., Rogoff, K. (Eds.), Macroeconomics Annual 2000. Cambridge, MIT Press for NBER. 
[40] Rose, A. (2005), "Which International Institutions Promote International Trade?", Review of International Economics 13(4): 682 - 698

[41] SaEz, E. (2002), "Optimal Income Transfer Programs: Intensive versus Extensive Labor Supply Responses", Quarterly Journal of Economics 117: 1039-1073.

[42] Santos S. And Tenreyro, S. (2006), "The log of gravity", Review of Economics and Statistics 88(4): 641-658.

[43] Scarpetta, S. (1996), "Assessing the Role of Labour Market Policies and Institutional Settings on Unemployment: A Cross-Country Study", OECD Economic Studies 26: $43-98$.

[44] Trefler, D. (2005), "The long and short of Canada-US free trade agreement", American Economic Review 94(4): 870-895. 


\section{A Data description and summary statistics}

\section{A.1 Unemployment rates}

Table 8: Unemployment rates according to different sources

\begin{tabular}{|c|c|c|c|c|c|c|}
\hline \multirow[t]{2}{*}{ Year } & \multirow[t]{2}{*}{ Sample } & \multicolumn{3}{|c|}{$\begin{array}{c}\text { Unemployment rate } \\
\text { (average) }\end{array}$} & \multicolumn{2}{|c|}{$\begin{array}{c}\text { ratio } \\
\mathrm{CIA} / \mathrm{ILO}\end{array}$} \\
\hline & & WDI & ILO & CIA & Avg. & Median \\
\hline \multirow[t]{3}{*}{1990} & Full $(\mathrm{N}=48)$ & 7.74 & 7.79 & 9.69 & 1.29 & 1.16 \\
\hline & OECD 20 & 6.90 & 6.88 & 7.02 & 1.07 & 1.00 \\
\hline & RoW & 8.16 & 8.24 & 11.03 & 1.40 & 1.18 \\
\hline \multirow[t]{3}{*}{1995} & Full $(\mathrm{N}=68)$ & 8.69 & 9.00 & 9.64 & 1.16 & 1.10 \\
\hline & OECD 20 & 8.74 & 8.75 & 10.39 & 1.22 & 1.17 \\
\hline & RoW & 8.68 & 9.10 & 9.34 & 1.13 & 1.08 \\
\hline \multirow[t]{3}{*}{2000} & Full $(\mathrm{N}=77)$ & 9.06 & 9.43 & 10.88 & 1.39 & 1.02 \\
\hline & OECD 20 & 6.15 & 6.13 & 6.73 & 1.09 & 1.03 \\
\hline & RoW & 10.09 & 10.59 & 12.34 & 1.50 & 1.02 \\
\hline \multirow[t]{3}{*}{2005} & Full $(\mathrm{N}=69)$ & 8.94 & 8.94 & 9.89 & 1.15 & 1.07 \\
\hline & OECD 20 & 6.39 & 6.34 & 6.63 & 1.04 & 1.03 \\
\hline & RoW & 9.98 & 9.99 & 11.23 & 1.20 & 1.08 \\
\hline \multicolumn{7}{|c|}{$\begin{array}{l}\text { Data sources: CIA (Central Intelligence Agency); ILO (International Labor } \\
\text { Organization), WDI (World Development Indicators, World Bank). } \\
\text { OECD20 sample includes the } 20 \text { OECD countries used in Bassanini \& } \\
\text { Duval (2009) and in our panel regressions. }\end{array}$} \\
\hline
\end{tabular}

Countries included: Albania $^{C}$, Argentina ${ }^{B C}$, Australia ${ }^{A B C}$, Austria ${ }^{A B C}$, Belgium ${ }^{A B C}$, Bolivia ${ }^{B C}$, Brazil $^{B C}$, Bulgaria ${ }^{B C}$, Canada ${ }^{A B C}$, Chile ${ }^{B C}$, China ${ }^{B C}$, Colombia ${ }^{B C}$, Costa Rica ${ }^{C}$, Croatia ${ }^{B C}$, Czech Republic $^{B C}$, Denmark ${ }^{A B C}$, Dominican Rep. ${ }^{B C}$, Ecuador ${ }^{B C}$, Egypt $^{B C}$, El Salvador ${ }^{C}$, Estonia ${ }^{C}$, Finland ${ }^{A B C}$, France $^{A B C}$, Germany ${ }^{A B C}$, Georgia ${ }^{C}$, Greece ${ }^{B C}$, Guatemala ${ }^{C}$, Honduras ${ }^{C}$, Hong Kong ${ }^{B C}$, Hungary ${ }^{B C}$, Iceland $^{C}$, Indonesia ${ }^{B C}$, Ireland ${ }^{A B C}$, Israel $^{B C}$, Italy ${ }^{A B C}$, Jamaica $^{B C}, \operatorname{Japan}^{A B C}, \operatorname{Jordan}^{C}$, Kazakstan $^{B}$,

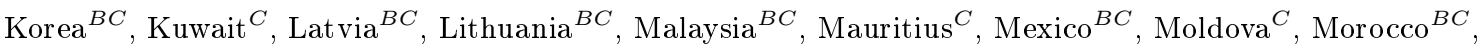
Netherlands ${ }^{A B C}$, New Zealand ${ }^{A B C}$, Nicaragua ${ }^{C}$, Norway ${ }^{A B C}$, Pakistan $^{B C}$, Panama ${ }^{B C}$, Paraguay ${ }^{C}$, Peru $^{B C}$, Philippines ${ }^{B C}$, Poland ${ }^{B C}$, Portugal ${ }^{A B C}$, Romania ${ }^{B C}$, Russian Federation ${ }^{B C}$, Singapore $^{B C}$, Slovak Republic ${ }^{B C}$, Slovenia ${ }^{B C}$, South Africa ${ }^{B C}$, Spain $^{A B C}$, Sri Lanka ${ }^{B C}$, Sweden ${ }^{A B C}$, Syria ${ }^{C}$, Switzerland ${ }^{A B C}$, Thailand $^{B C}$, Tunisia $^{C}$, Turkey ${ }^{B C}$, Ukraine $^{B C}$, United Kingdom ${ }^{A B C}$, United States ${ }^{A B C}$, Uruguay ${ }^{B C}$, Venezuela ${ }^{B C}$. $A$ : included in the OECD sample, $B$ : included in the large cross section, $C$ : included in the large panel.

\section{A.2 OECD sample}

Unemployment rates (U) For our OECD benchmark regressions we use total unemployment, measuring the percentage share of unemployed workers in toad labor force ( 15 - 66 years old individuals). 
Data taken from Basanini and Duval. Original Source: OECD, Database on Labour Force Statistics; OECD, Annual Labour Force Statistics.

Openness measures ( $\mathbf{T}$ ) Total trade openness is defined as imports plus exports divided by two times GDP in current prices. Real openness measures are constructed as respective current price openness measure times price level (taken from the Penn World Table 6.2) in order to accounts for the Balassa Samuelson effect by using real purchasing power GDP as denominator. Open (merchandise) excludes services, taken from the WDI data base and constant price openness taken from the Penn World Table 6.2 .

Wage distortion Wage distortion lumps replacement rate and tax wedge together. Both variables affect unemployment through the same channel, namely wages. Therefore lumping both variables together further reduces the number of instruments when estimating GMM regressions.

Replacement rate Average unemployment benefits taken from the Basanini and Duval data set. Original source: OECD Benefits and Wages Database. According to Basanini and Duval data is available for odd years only, so that they filled the gaps by linear interpolation. 


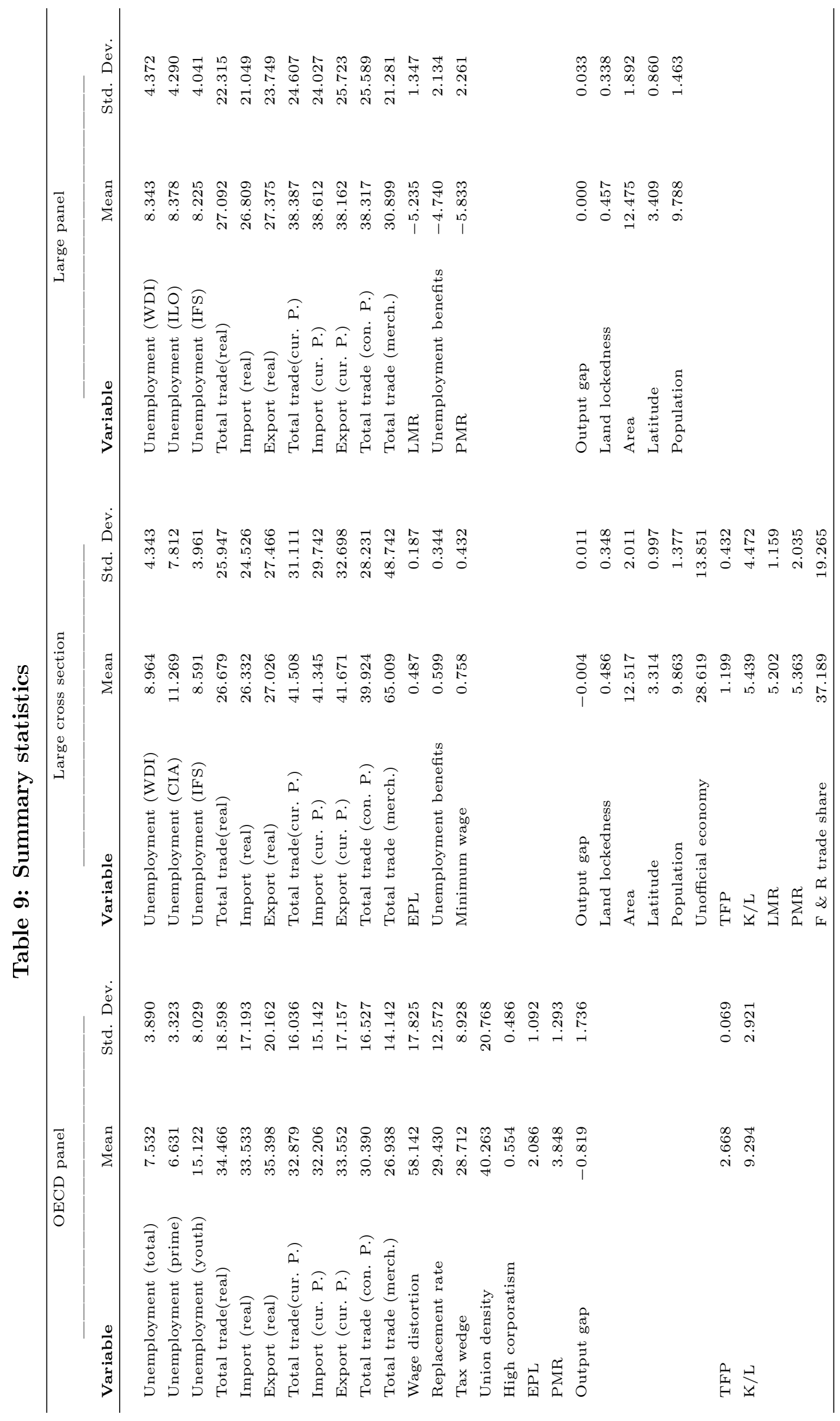


Tax wedge This variable measures taxation on wages by computing the difference between wages paid by employers and wages earned by employees. The variable on tax wedge is build on the OECD taxing wages data. Some observations were adjusted by B\&D in order to fill the gaps in the data, thus providing a complete sample for the period $1982-2003$.

Union density Union density measures the percentage share of workers associated to unions. According to B\&D the data was taken from the OECD Employment Outlook 2004 and inter / extrapolated in order to maximize the sample.

High corporatism Dummy variable that takes the value one if wage bargaining is highly centralized. Source: Basanini and Duval.

EPL Measures the stringency of employment protection legislation, taken from Basanini and Duval. Original source: OECD, Employment Outlook 2004.

PMR Measures the regulation on product markets and competition, taken from Basanini and Duval. Original source: Conway et al. (2006).

Total factor productivity (TFP) We construct total factor productivity according to Benhabib and Spiegel (2004) as Solow residual. We assume that GDP is produced according to a Cobb Douglas production function and obtain the Solow residual as difference between ln GDP and ln labor as well as ln capital input. For the Cobb Douglas input shares we use standardized values.

Capital to labor ratio $(\mathbf{K} / \mathbf{L})$ The capital to labor ratio is constructed according to Benhabib and Spiegel (2005). Capital is the sum of discounted initial capital, discounted and inherited capital from the lagged periods, and investment made in the respective period. For labor we use data on population as a proxy. We use Penn World Table 6.2 data for population, investment and GDP.

Output gap Output gap measures the difference between actual and potential GDP as percentage of potential output. As source B\&D cite the OECD Economic outlook and IMF International finance statistics.

\section{A.3 Large global cross country sample}

Unemployment rate (U) We use three different sources for total unemployment: The World Developing Indicators mainly provide official estimates on unemployment and are used as benchmark. Average unemployment rates constructed with less than 10 observations dropped. For additional robustness checks we include unemployment rates taken from the CIA factbook and IFS data base.

Openness measures (T) See OECD sample data description for further details. 
Frankel and Romer instrument (F\&R) Our improved Frankel and Romer instrument bilateral trade data was used to regress total trade (exports plus imports) between country $i$ and $j$, normalized by country $i^{\prime} s$ GDP, on geographical determinants of trade. The standard procedure is to take logs and estimate using OLS. Since $T_{i j}=0$ for many country pairs, we follow Santos and Tenreyro (2006) and estimate (3) using Poisson pseudo maximum-likelihood. Predicting $\hat{T}_{i j}$ and summing over $j$, we have a measure of the trade share $\hat{T}_{i}$ that is by construction orthogonal to unemployment and hence a valid instrument.

EPL Employment laws index measuring the protection of labor and employment (EPL). The index variable includes: 1) Alternative employment contracts, 2) cost of increasing hours worked, 3) cost of firing workers and 4) dismissal procedures. Source: Botero et al. (2004).

Unemployment benefits Unemployment benefits is an index variable taken from Botero et al. (2004), including: 1) time of employment needed to qualify for unemployment benefits, 2) percentage of workers monthly income, paid to finance unemployment benefits, 3) waiting time on unemployment benefits, 4) percentage of income covered by unemployment benefits in case of a one year unemployment spell.

Minimum wage Dummy variable which takes the value one if there are binding minimum wages in the respective economy, taken from Botero et al. (2004).

Latitude Measures the distance between a country's capital and the equator. Data taken from the CIA factbook.

Area We control for the size of the economy in terms of its log area.

Land lockedness Land lockedness is constructed as index, measuring the length of neighboring borders relative to total length of borders.

Population We use Penn World Table 6.2 data on the size of population and take logs.

Unofficial economy This variable measures the size of the shadow economy, taken from Botero et al. (2004).

Total factor productivity (TFP) We use the original log TFP data provided by Benhabib and Spiegel (2005), constructed as difference between log GDP and log capital, as well as log labor input.

Capital to labor ratio $(\mathbf{K} / \mathbf{L})$ See OECD data description for further details.

Output gap We construct output gap as difference between ln GDP and ln trend GDP, where the latter one is constructed by HP filtering the GDP data with smoothing factor 400. GDP is constructed as real GDP per capita (chain) times population taken from the Penn World Table 6.2. 


\section{A.4 Large panel}

Unemployment rates (U) See large cross section for further details. We also use unemployment rates from the ILO Laborsta database for robustness checks.

Openness measures See OECD data description for further details.

Labor market regulations (LMR) An index variable capturing labor market regulations. This index contains information on minimum wages, mandated hiring costs, unemployment benefits and other variables. Notice that higher index values indicate more freedom and thus lower labor market regulations. Higher values indicate more freedom in terms of less regulation. Between 1975 and 2000 data was estimated in 5-year intervals. From 2000 till 2006 yearly data is available. Source: Fraser Freedom of the World data set, 2008. Recoded by multiplying with -1 .

Unemployment benefits Higher values indicate more freedom in terms of less regulation. Source: Fraser Freedom of the World Data set, 2008. Recoded by multiplying with -1 .

Product market regulations (PMR) Taken from the Fraser freedom of the world database. We use price control as proxy for product market regulations. Higher values indicate more freedom in terms of less regulation. Source: Fraser Freedom of the World data set, 2008. Recoded by multiplying with -1 .

Output gap See large cross section data description for more details.

Population See large cross section data description for more details. 